INTER NATIONAL MONETARY FUND
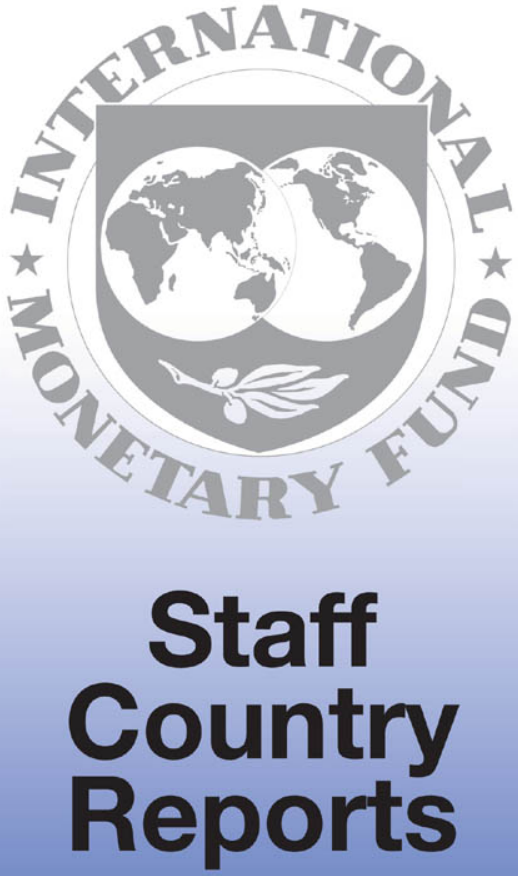


\section{Djibouti: Staff-Monitored Program}

This paper on the staff-monitored program for Djibouti was prepared by a staff team of the International Monetary Fund as background documentation for the periodic consultation with the member country. It is based on the information available at the time it was completed on May 26, 2004. The views expressed in this document are those of the staff team and do not necessarily reflect the views of the government of the Djibouti or the Executive Board of the IMF.

The policy of publication of staff reports and other documents by the IMF allows for the deletion of market-sensitive information.

To assist the IMF in evaluating the publication policy, reader comments are invited and may be sent by e-mail to publicationpolicy@imf.org.

Copies of this report are available to the public from

International Monetary Fund • Publication Services

$70019^{\text {th }}$ Street, N.W. • Washington, D.C. 20431

Telephone: (202) 623-7430 • Telefax: (202) 623-7201

E-mail: publications@imf.org •Internet: http://www.imf.org

Price: $\$ 15.00$ a copy

\section{International Monetary Fund \\ Washington, D.C.}


This page intentionally left blank 
INTERNATIONAL MONETARY FUND

\title{
DJIBOUTI
}

\section{Staff-Monitored Program}

\section{Prepared by the Middle East and Central Asia Department}

(In consultation with other departments)

\author{
Approved by Sena Eken and G. Russell Kincaid
}

May 26, 2004

- Discussions on a staff-monitored program (SMP) were held in Djibouti from December 7 to December 15, 2003 and from February 21 to February 29, 2004. The mission met with Prime Minister Dileita; Economy, Finance, and Planning Minister Bouh; Central Bank Governor Haïd; other senior officials; and representatives of bilateral donors and multilateral organizations.

- The staff team included Messrs. Fasano (head), Dridi (participated in the December mission), Peter (all MCD), and Ms. Bhattacharya (FAD). Mr. Kumah, the IMF resident representative, assisted the missions and participated in the discussions. Ms. Eken, Assistant Director in MCD, participated in the policy meetings during the December 2003 mission. Mr. SidiBouna, advisor to Mr. Ondo-Mañe, Executive Director for Djibouti, attended the policy meetings during the February 2004 mission.

- Last Article IV Consultation. At the time of the 2003 Article IV discussions on January 7, 2004, Directors considered that in light of Djibouti's weak track record of policy reforms under the 1999-2002 Poverty Reduction and Growth Facility (PRGF) arrangement, an effective and well-focused SMP will provide an appropriate framework for assisting the authorities in reestablishing their credibility and demonstrate their commitment to policy reforms.

- $\quad$ SMP. In the attached Letter of Intent (LOI) and Memorandum of Economic and Financial Policies (MEFP) (Attachments I and II, respectively), the authorities have indicated their intention to implement a 12-month SMP covering the period January-December 2004, including prior actions, indicative targets, structural benchmarks, and a detailed policy matrix.

- SMP objectives. In line with Board recommendations at the time of the last Article IV consultation, the program aims at further strengthening the fiscal position, reducing domestic arrears, and completing the unfinished reform agenda of the previous PRGF arrangement. Such a program should enhance growth prospects and help the authorities establish a strong track record of policy reforms, laying the foundation for an envisaged successor PRGF arrangement.

- The principal authors of the report are U. Fasano, M. Peter, and R. Bhattacharya. 


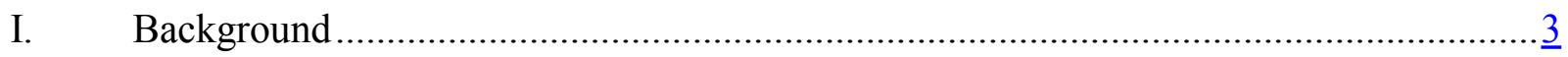

II. Recent Economic Developments ................................................................... $\underline{3}$

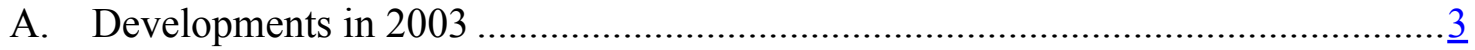

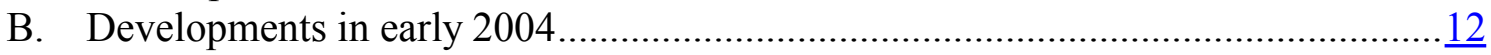

III. Policy Discussions ...................................................................................... 14

A. The Macroeconomic Framework and Policies ............................................14

B. Structural Reforms ...........................................................................

IV. Program Risks and Monitoring ......................................................................21

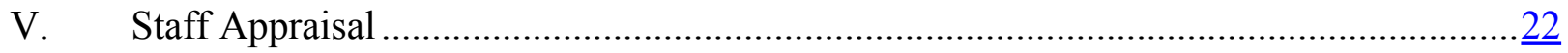

Text Box

1. 2003 Article IV Consultation-Main Policy Recommendations ................................15

Figures

1. Selected Economic Indicators Before and After

Two IMF-Supported Programs .................................................................

2. Real Effective Exchange Rate Index, Jan. 1999-Jan. 2004........................................ $\underline{9}$

Tables

1. Selected Economic and Financial Indicators, 1999-2004 ........................................

2. Central Government Fiscal Operations, 1999-2004 ..............................................

3. Balance of Payments, 1999-2004 ........................................................................ 10

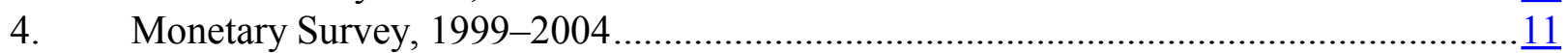

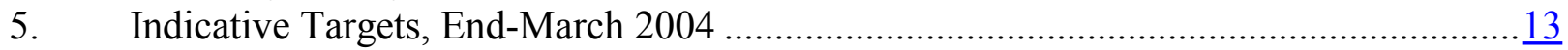

6. Millennium Development Goals, 1990-2015 ......................................................

Appendices

I. Performance under Previous Fund-Supported Programs...........................................24

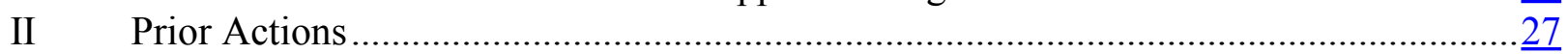

III. Relations with the Fund .............................................................................

IV. Relations with the World Bank..........................................................................

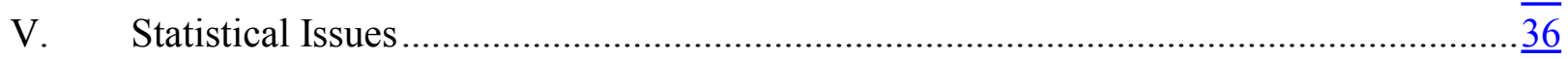

Attachments

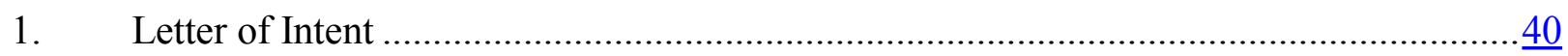

2. Memorandum on Economic and Financial Policies ................................................. 42 


\section{BACKGROUND}

1. Djibouti's macroeconomic performance and progress in adopting structural reforms under the 1999-2002 PRGF arrangement were mixed due to a combination of external and internal factors. These included the instability in the region, the inflow of refugees, and a protracted domestic peace process following the end of the civil war in 1994. In addition, political considerations, particularly around election time in 1999 and 2002, slowed down the adoption of policy reforms. Although real GDP growth picked up amid low inflation, it remained insufficient to boost per capita income (Figure 1). Fiscal balance indicators continued to record, on average, deficits of about the same level in percent of GDP as during the previous three years under the Fund's 1996-99 stand-by arrangement, because the decline in the wage bill (mainly through the demobilization of ex-combatants and cut in nominal wages) was offset by lower tax receipts (on account of tax exemptions and weak collection) as well as increases in investment spending. ${ }^{1}$ On the structural side, fiscal reforms (the simplification of the tax structure, the improvement in tax administration, and the rationalization of budget management) advanced - albeit with significant delays - while key measures to address the longstanding loss in external competitiveness (including the adoption of a new investment and labor code) stalled.

\section{The Djibouti authorities requested in July 2003 a successor PRGF arrangement.}

Given their poor track record of policy reforms under the previous arrangement, the staff saw the need for decisive policy implementation before entering into a new Fund-supported program and, thereby, recommended a 12-month SMP covering the calendar year 2004. Moreover, a number of Executive Directors had already indicated in December 2002, when completing the last review of the previous PRGF arrangement, and in January 2004, at the time of the 2003 Article IV discussions, that a period of solid policy performance will have to precede Board consideration of any successor PRGF arrangement.

\section{RECENT ECONOMIC DEVELOPMENTS}

\section{A. Developments in $\mathbf{2 0 0 3}$}

3. Djibouti's fiscal position improved significantly in 2003, mainly reflecting a large increase in revenue from military cooperation agreements. Indeed, Djibouti received the equivalent of about 4.4 percent of GDP in additional resources from medium- and long-term military agreements with the United States (including a one-off payment of about 0.6 percent

\footnotetext{
${ }^{1}$ Appendix I summarizes Djibouti’s performance under Fund-supported programs.
} 
Figure 1. Djibouti: Selected Economic Indicators Before and After Two IMF-Supported Programs
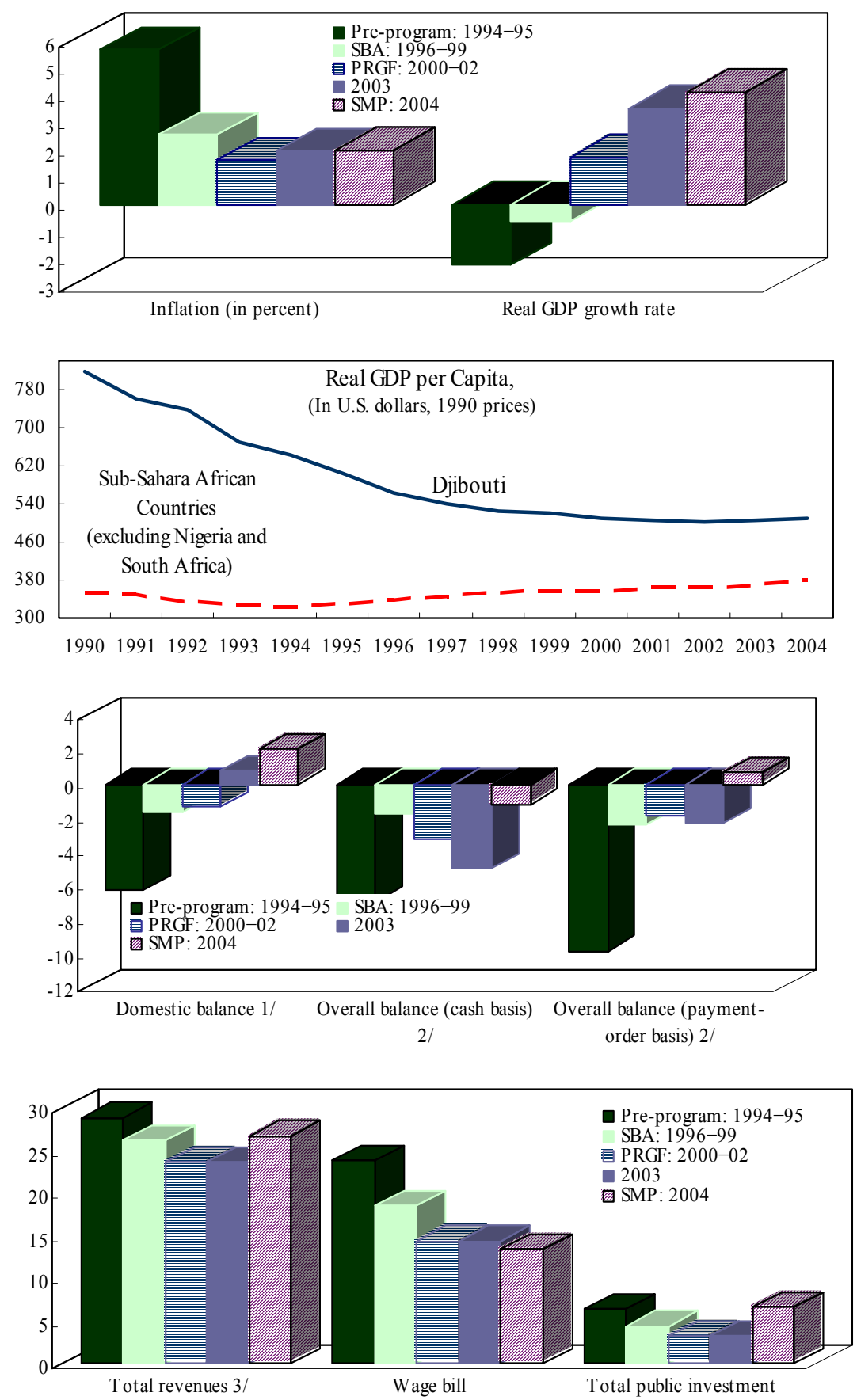

Sources: Djibouti authorities; and IMF staff estimates and projections.

$1 /$ Total revenue (excluding grants) less total domestically financed current and capital expenditures.

2 / Including grants.

3/ Includes direct and indirect tax revenues; and non tax receipts. 
of GDP) and France, respectively, as well as nonearmarked grants from Spain. ${ }^{2}$ The overall fiscal deficit (on a payment-order basis) declined from 3.5 percent of GDP in 2002 to 2.3 percent in 2003, and the domestic fiscal balance ${ }^{3}$ moved from a deficit of 2 percent of GDP to an estimated surplus of close to 1 percent over the same period (Tables 1 and 2). Moreover, the authorities accelerated the clearance of domestic arrears in 2003, which declined by 2.7 percent of GDP to 23.6 percent by the end of the year. In addition, practically all external payment arrears to multilateral institutions were cleared by end- 2003 .

4. Excluding the defense-related receipts from France and the United States, however, the domestic fiscal balance deteriorated by 1.1 percent of GDP to 4.2 percent (Table 2). ${ }^{4}$ This deterioration was the result of a 1.8 percent of GDP increase in domestically financed expenditures, as other domestic revenue (mainly indirect taxes) increased by about 0.7 percent of GDP to 23.1 percent - one of the highest ratios among low-income countries. Current spending increased by about 1.1 percent of GDP, mainly as a result of higher transfers, a one-off back payment of wages and benefits to teachers hired in September 2002 (whose appointments were regularized in early 2003), and a rise in peace agreement-related spending. ${ }^{5}$ Domestically financed investment increased by 0.7 percent of GDP, reflecting the establishment of two new publicly owned enterprises (a water desalination and bottling factory and a cement production company); ${ }^{6}$ thus, aggravating the current imbalance between public and private sectors in the Djibouti economy.

\footnotetext{
${ }^{2}$ France signed in late 2002 a 10 -year contract with Djibouti for the payment of services provided by the Djibouti government to, and taxes paid by, the French military forces stationed in the country. The United States agreed with Djibouti on a two-year contract beginning in October 2002 for the rent of a military base, with the contract to be renegotiated toward the end of 2004. These defense-related receipts are not earmarked and are fixed in nominal terms (in euros and in U.S. dollars, respectively) over the time of the contracts.
}

${ }^{3}$ The domestic fiscal balance is defined as total government revenue (excluding foreign grants but including revenues from defense-related services provided to France and the United States) minus domestically financed expenditures.

${ }^{4}$ In a macroeconomic sense, rental payments for a military base as well as defense-related receipts from France are similar to foreign grants. For this reason, it is helpful to analyze Djibouti's fiscal effort by leaving them out of the calculation of the domestic fiscal balance; thus, capturing policy actions under full control of the authorities.

${ }^{5}$ The authorities explained that the peace agreement-related spending reflected the electrification of part of the countryside.

${ }^{6}$ A third publicly owned company (that will extract natural stones) is expected to start operations in the near future financed through a bilateral loan. 
Table 1. Djibouti: Selected Economic and Financial Indicators, 1999-2004

\begin{tabular}{|c|c|c|c|c|c|c|}
\hline & 1999 & 2000 & 2001 & 2002 & $\frac{2003}{\text { Est. }}$ & $\frac{2004}{\text { Proj. }}$ \\
\hline \multicolumn{7}{|l|}{ National income and prices } \\
\hline Nominal GDP (in millions of Djibouti francs) & 95,273 & 98,267 & 101,932 & 105,210 & 111,070 & 117,971 \\
\hline Real GDP (annual change in percent) & 2.2 & 0.7 & 1.9 & 2.6 & 3.5 & 4.1 \\
\hline \multirow[t]{2}{*}{ Consumer prices (annual average) } & 2.0 & 2.4 & 1.8 & 0.6 & 2.0 & 2.0 \\
\hline & \multicolumn{6}{|c|}{ (In percent of GDP) } \\
\hline Investment $1 /$ & 8.8 & 12.2 & 8.3 & 10.9 & 15.5 & 20.6 \\
\hline National saving & 8.2 & 5.1 & 2.7 & 4.1 & 7.9 & 10.3 \\
\hline \multicolumn{7}{|l|}{ Central government operations } \\
\hline Total revenue and grants & 30.9 & 31.0 & 28.2 & 29.4 & 34.2 & 35.4 \\
\hline Of which: Tax revenue & 21.6 & 21.5 & 20.5 & 21.1 & 22.7 & 21.9 \\
\hline Total expenditures & 33.1 & 32.8 & 29.6 & 32.9 & 36.5 & 34.8 \\
\hline Of which: Investment expenditures & 3.1 & 2.7 & 2.5 & 4.5 & 6.7 & 6.7 \\
\hline Overall balance (payment order basis) & -2.2 & -1.8 & -1.4 & -3.5 & -2.3 & 0.7 \\
\hline Change in total arrears (decrease -) & 1.3 & 0.5 & -0.6 & -0.7 & -2.7 & -1.8 \\
\hline Overall balance (cash basis) & -0.8 & -1.3 & -2.0 & -4.2 & -5.0 & -1.2 \\
\hline Government domestic arrears (stock) 2/ & 29.3 & 29.6 & 28.9 & 27.8 & 23.6 & 20.3 \\
\hline Domestic fiscal balance $3 /$ & -2.6 & -1.6 & -0.3 & -2.0 & 0.8 & 2.1 \\
\hline Total gross public debt $4 /$ & 97.9 & 101.1 & 99.0 & 100.6 & 98.3 & 93.5 \\
\hline & \multicolumn{6}{|c|}{ (Change from preceding December; in percent of broad money)5/ } \\
\hline \multicolumn{7}{|l|}{ Money and credit } \\
\hline Broad money & 5.2 & 1.1 & 7.5 & 15.7 & 17.8 & 5.0 \\
\hline Net foreign assets & 5.7 & -7.3 & 16.1 & 15.7 & 19.4 & 4.4 \\
\hline Net domestic assets & -0.5 & 8.4 & -8.6 & 0.0 & -1.6 & 0.6 \\
\hline \multicolumn{7}{|l|}{ Of which } \\
\hline Claims on the central government (net) & -0.2 & 1.2 & 1.1 & 2.8 & 0.5 & -0.4 \\
\hline \multirow[t]{2}{*}{ Claims on nongovernment sector } & 2.7 & 5.2 & -8.2 & -2.9 & -1.2 & 1.0 \\
\hline & \multicolumn{6}{|c|}{ (In millions of US dollars; unless otherwise indicated) } \\
\hline \multicolumn{7}{|l|}{ External sector } \\
\hline Current account & -1.9 & -39.7 & -31.9 & -40.1 & -47.4 & -68.6 \\
\hline (in percent of GDP) & -0.6 & -7.2 & -5.6 & -6.8 & -7.6 & -10.3 \\
\hline \multicolumn{7}{|l|}{ Of which } \\
\hline Trade balance & -182.4 & -194.8 & -187.4 & -204.1 & -249.2 & -289.2 \\
\hline Transfers (net) & 62.7 & 53.1 & 32.7 & 40.6 & 43.6 & 63.0 \\
\hline Capital account & -1.2 & 30.7 & 10.2 & 34.9 & 59.7 & 82.1 \\
\hline Overall balance & 7.9 & -18.1 & 39.9 & 49.8 & 65.2 & 19.1 \\
\hline \multicolumn{7}{|l|}{ Official external debt } \\
\hline (in percent of GDP) 6/ & 62.8 & 66.9 & 65.2 & 66.8 & 68.3 & 67.5 \\
\hline \multicolumn{7}{|l|}{ Debt service to exports of goods and services $7 /$} \\
\hline Obligations basis after rescheduling & 8.2 & 7.3 & 7.3 & 7.4 & 7.9 & 7.6 \\
\hline \multicolumn{7}{|l|}{ Memorandum items } \\
\hline Net international reserves (in millions of U.S. dollars) & 7.5 & 8.7 & 9.5 & 9.6 & 12.2 & 12.2 \\
\hline \multicolumn{7}{|l|}{ Exchange rate } \\
\hline Exchange rate (DF/US\$) end-of-period & 177.7 & 177.7 & 177.7 & 177.7 & 177.7 & $\ldots$ \\
\hline \multicolumn{7}{|l|}{ Real effective exchange rate } \\
\hline (End-year change in percent; depreciation -) & 6.7 & 9.3 & 3.3 & -8.4 & -11.5 & $\ldots$ \\
\hline
\end{tabular}

Sources: Djibouti authorities; and Fund staff estimates and projections.

1/ The increase in 2003 and 2004 reflects the start of construction of the oil terminal and new port facility.

2/ Domestic arrears include wage arrears and arrears to private and public suppliers for goods and services and the pension funds.

3/ Total revenue (excluding grants) less total domestically financed current and capital expenditures.

$4 /$ Includes public and publicly guaranteed external and domestic debt and all arrears.

5/ Beginning in 1998, data include only three operating banks.

6/ Public and publicly guaranteed debt of the central government and public enterprises.

7/ Exports of locally produced goods and nonfactor services. 
Table 2. Djibouti: Central Government Fiscal Operations, 1999-2004

(In millions of Djibouti francs)

\begin{tabular}{|c|c|c|c|c|c|c|c|}
\hline & 1999 & 2000 & 2001 & 2002 & $\frac{2003}{\text { Est. }}$ & $\frac{2004}{\text { Budget }}$ & $\begin{array}{r}2004 \\
\text { Proj. } 1 /\end{array}$ \\
\hline Revenues and grants & 29,429 & 30,467 & 28,774 & 30,947 & 37,962 & 41,292 & 41,796 \\
\hline Total revenue & 22,362 & 23,969 & 23,702 & 24,720 & 31,220 & 31,623 & 31,623 \\
\hline Tax revenue & 20,605 & 21,099 & 20,862 & 22,164 & 25,222 & 25,851 & 25,851 \\
\hline Direct taxes & 8,469 & 8,780 & 9,248 & 9,804 & 10,281 & 10,705 & 10,705 \\
\hline Indirect taxes & 12,136 & 12,319 & 11,614 & 12,360 & 14,941 & 15,146 & 15,146 \\
\hline $\begin{array}{r}\text { Of which: Military agreement } \\
\text { with France } 2 /\end{array}$ & & & & 1,157 & 2,294 & 2,230 & 2,230 \\
\hline & \multicolumn{2}{|c|}{ Of which: Rental payment for military } & 2,840 & 2,556 & 5,998 & 5,773 & 5,773 \\
\hline base by the U.S. & 0 & 0 & 0 & 0 & 3,289 & 2,666 & 2,666 \\
\hline \multicolumn{8}{|l|}{ Of which } \\
\hline Nonearmarked grants & 1,090 & 1,020 & 876 & 1,042 & 1,350 & 1,100 & 1,100 \\
\hline Project related grants & 1,843 & 1,633 & 881 & 1,799 & 849 & 3,505 & 4,009 \\
\hline Total expenditure & 31,490 & 32,204 & 30,215 & 34,660 & 40,490 & 40,114 & 41,013 \\
\hline Current expenditure & 28,575 & 29,564 & 27,688 & 29,965 & 33,054 & 33,151 & 33,151 \\
\hline Wages and salaries 3 / & 14,694 & 14,609 & 14,804 & 14,721 & 15,819 & 15,943 & 15,943 \\
\hline Of which: Cost of demobilization & 89 & 173 & 208 & 354 & 0 & 178 & 178 \\
\hline Goods and services $4 /$ & 6,463 & 5,991 & 4,709 & 6,544 & 7,992 & 7,421 & 7,421 \\
\hline Of which: Foreign financed military expenditures & 870 & 360 & 360 & 360 & 1,517 & 1,517 & 1,517 \\
\hline Maintenance & 365 & 715 & 515 & 606 & 480 & 650 & 650 \\
\hline Transfers & 3,195 & 3,762 & 3,533 & 3,717 & 4,203 & 4,350 & 4,350 \\
\hline Interest payments & 499 & 463 & 301 & 239 & 389 & 535 & 535 \\
\hline Peace agreement spending & 0 & 0 & 0 & 363 & 700 & 350 & 350 \\
\hline Foreign-financed development programs & 3,179 & 4,024 & 3,826 & 3,774 & 3,471 & 3,902 & 3,902 \\
\hline Investment expenditure & 2,915 & 2,640 & 2,527 & 4,695 & 7,436 & 6,962 & 7,862 \\
\hline Domestically financed & 399 & 531 & 709 & 1,371 & 2,224 & 1,619 & 1,619 \\
\hline Foreign-financed & 2,516 & 2,109 & 1,818 & 3,324 & 5,212 & 5,344 & 6,243 \\
\hline $\begin{array}{l}\text { Overall balance (payment-order basis, including } \\
\text { grants) }\end{array}$ & $-2,061$ & $-1,737$ & $-1,441$ & $-3,713$ & $-2,528$ & 1,178 & 783 \\
\hline Change in arrears (payments $=-$ ) & 1,272 & 466 & -605 & -695 & $-3,031$ & $-2,165$ & $-2,165$ \\
\hline Of which: Domestic arrears & 1,482 & 308 & -631 & -658 & $-3,065$ & $-2,165$ & $-2,165$ \\
\hline Overall balance (cash basis) & -789 & $-1,271$ & $-2,046$ & $-4,408$ & $-5,558$ & -987 & $-1,382$ \\
\hline Financing & 789 & 1,271 & 2,046 & 4,407 & 5,468 & 1,005 & 1,382 \\
\hline Domestic financing & 320 & 645 & 598 & 1,578 & 211 & -415 & -415 \\
\hline Net bank financing & 278 & 645 & 598 & 1,578 & 307 & -319 & -319 \\
\hline Central bank & 798 & 602 & 579 & 146 & 476 & -131 & -131 \\
\hline Commercial banks & -520 & 43 & 19 & 1,432 & -169 & -187 & -187 \\
\hline Net nonbank financing & 42 & 0 & 0 & 0 & -96 & -96 & -96 \\
\hline Net external financing & 469 & 626 & 1,447 & 2,829 & 5,257 & 1,420 & 1,797 \\
\hline Disbursements & 845 & 1,015 & 1,808 & 3,494 & 5,697 & 2,194 & 2,571 \\
\hline Amortization payments & -376 & -389 & -361 & -665 & -440 & -774 & -774 \\
\hline Residual & 0 & 0 & 0 & 0 & 90 & -18 & 0 \\
\hline \multicolumn{8}{|l|}{ Memorandum items: } \\
\hline $\begin{array}{l}\text { Domestic fiscal balance } 5 / \\
\text { (excluding military-related receipts from }\end{array}$ & $-2,474$ & $-1,569$ & -301 & $-2,128$ & 930 & 2,450 & 2,450 \\
\hline France and the U.S.) & $\ldots$ & $\ldots$ & $\ldots$ & $-3,285$ & $-4,653$ & $-2,446$ & $-2,446$ \\
\hline $\begin{array}{l}\text { Domestic revenue } \\
\text { (excluding military-related receipts from }\end{array}$ & 22,362 & 23,969 & 23,702 & 24,720 & 31,220 & 31,623 & 31,623 \\
\hline France and the U.S.) & $\ldots$ & $\ldots$ & $\ldots$ & 23,563 & 25,637 & 26,727 & 26,727 \\
\hline Domestically financed expenditures 6/ & 24,656 & 25,538 & 24,003 & 26,848 & 30,290 & 29,174 & 29,173 \\
\hline (in percent of total expenditure) & 78.9 & 79.3 & 79.4 & 77.5 & 74.8 & 72.7 & 71.1 \\
\hline Grants in percent of total government revenue & 24.0 & 21.3 & 17.6 & 20.1 & 17.8 & 23.4 & 24.3 \\
\hline
\end{tabular}


Table 2. Djibouti: Central Government Fiscal Operations, 1999-2004 (concluded)

(In percent of GDP)

\begin{tabular}{|c|c|c|c|c|c|c|c|}
\hline & 1999 & 2000 & 2001 & 2002 & $\frac{2003}{\text { Est. }}$ & $\underline{2004}$ & $\begin{array}{r}2004 \\
\text { Proj. } 1 /\end{array}$ \\
\hline Revenues and grants & 30.9 & 31.0 & 28.2 & 29.4 & 34.2 & 35.0 & 35.4 \\
\hline Total revenue & 23.5 & 24.4 & 23.3 & 23.5 & 28.1 & 26.8 & 26.8 \\
\hline Tax revenue & 21.6 & 21.5 & 20.5 & 21.1 & 22.7 & 21.9 & 21.9 \\
\hline Direct taxes & 8.9 & 8.9 & 9.1 & 9.3 & 9.3 & 9.1 & 9.1 \\
\hline \multicolumn{8}{|l|}{ Of which: Military agreement } \\
\hline with France 2/ & $\ldots$ & $\ldots$ & $\ldots$ & 1.1 & 2.1 & 1.9 & 1.9 \\
\hline \multicolumn{8}{|l|}{ Of which: Rental payment for military } \\
\hline base by the U.S. & 0.0 & 0.0 & 0.0 & 0.0 & 3.0 & 2.3 & 2.3 \\
\hline \multicolumn{8}{|l|}{ Of which: } \\
\hline $\begin{array}{l}\text { Nonearmarked grants } \\
\text { Project related grants }\end{array}$ & $\begin{array}{l}1.1 \\
1.9\end{array}$ & $\begin{array}{l}1.0 \\
1.7\end{array}$ & $\begin{array}{l}0.9 \\
0.9\end{array}$ & $\begin{array}{l}1.0 \\
1.7\end{array}$ & $\begin{array}{l}1.2 \\
0.8\end{array}$ & $\begin{array}{l}0.9 \\
3.0\end{array}$ & $\begin{array}{l}0.9 \\
3.4\end{array}$ \\
\hline Total expenditure & 33.1 & 32.8 & 29.6 & 32.9 & 36.5 & 34.0 & 34.8 \\
\hline Current expenditure & 30.0 & 30.1 & 27.2 & 28.5 & 29.8 & 28.1 & 28.1 \\
\hline Wages and salaries $3 /$ & 15.4 & 14.9 & 14.5 & 14.0 & 14.2 & 13.5 & 13.5 \\
\hline Of which: Cost of demobilization & 0.1 & 0.2 & 0.2 & 0.3 & 0.0 & 0.2 & 0.2 \\
\hline Goods and services 4/ & 6.8 & 6.1 & 4.6 & 6.2 & 7.2 & 6.3 & 6.3 \\
\hline Of which: Foreign financed military expenditures & 0.9 & 0.4 & 0.4 & 0.3 & 1.4 & 1.3 & 1.3 \\
\hline Maintenance & 0.4 & 0.7 & 0.5 & 0.6 & 0.4 & 0.6 & 0.6 \\
\hline Transfers & 3.4 & 3.8 & 3.5 & 3.5 & 3.8 & 3.7 & 3.7 \\
\hline Interest payments & 0.5 & 0.5 & 0.3 & 0.2 & 0.4 & 0.5 & 0.5 \\
\hline Peace agreement spending & 0.0 & 0.0 & 0.0 & 0.3 & 0.6 & 0.3 & 0.3 \\
\hline Foreign-financed development programs & 3.3 & 4.1 & 3.8 & 3.6 & 3.1 & 3.3 & 3.3 \\
\hline Investment expenditure & 3.1 & 2.7 & 2.5 & 4.5 & 6.7 & 5.9 & 6.7 \\
\hline Domestically financed & 0.4 & 0.5 & 0.7 & 1.3 & 2.0 & 1.4 & 1.4 \\
\hline Foreign financed & 2.6 & 2.1 & 1.8 & 3.2 & 4.7 & 4.5 & 5.3 \\
\hline Overall balance (payment-order basis, including grants) & -2.2 & -1.8 & -1.4 & -3.5 & -2.3 & 1.0 & 0.7 \\
\hline $\begin{array}{c}\text { Change in arrears (payments }=- \text { ) } \\
\text { Of which: Domestic arrears }\end{array}$ & $\begin{array}{l}1.3 \\
1.6\end{array}$ & $\begin{array}{l}0.5 \\
0.3\end{array}$ & $\begin{array}{l}-0.6 \\
-0.6\end{array}$ & $\begin{array}{l}-0.7 \\
-0.6\end{array}$ & $\begin{array}{l}-2.7 \\
-2.8\end{array}$ & $\begin{array}{l}-1.8 \\
-1.8\end{array}$ & $\begin{array}{l}-1.8 \\
-1.8\end{array}$ \\
\hline Overall balance (cash basis) & -0.8 & -1.3 & -2.0 & -4.2 & -5.0 & -0.8 & -1.2 \\
\hline Financing & 0.8 & 1.3 & 2.0 & 4.2 & 4.9 & 0.9 & 1.2 \\
\hline Net domestic financing & 0.3 & 0.7 & 0.6 & 1.5 & 0.2 & -0.4 & -0.4 \\
\hline Bank financing & 0.3 & 0.7 & 0.6 & 1.5 & 0.3 & -0.3 & -0.3 \\
\hline Net nonbank financing & 0.0 & 0.0 & 0.0 & 0.0 & -0.1 & -0.1 & -0.1 \\
\hline Net external financing & 0.5 & 0.6 & 1.4 & 2.7 & 4.7 & 1.2 & 1.5 \\
\hline Disbursements & 0.9 & 1.0 & 1.8 & 3.3 & 5.1 & 1.9 & 2.2 \\
\hline Amortization payments & -0.4 & -0.4 & -0.4 & -0.6 & -0.4 & -0.7 & -0.7 \\
\hline Residual & 0.0 & 0.0 & 0.0 & 0.0 & 0.1 & 0.0 & 0.0 \\
\hline \multicolumn{8}{|l|}{ Memorandum items } \\
\hline $\begin{array}{l}\text { Domestic fiscal balance } 5 / \\
\text { (excluding military-related receipts from }\end{array}$ & -2.6 & -1.6 & -0.3 & -2.0 & 0.8 & 2.1 & 2.1 \\
\hline France and the U.S.) & $\ldots$ & $\ldots$ & $\ldots$ & -3.1 & -4.2 & -2.1 & -2.1 \\
\hline $\begin{array}{l}\text { Domestic revenue } \\
\text { (excluding military-related receipts from }\end{array}$ & 23.5 & 24.4 & 23.3 & 23.5 & 28.1 & 26.8 & 26.8 \\
\hline France and the U.S.) & $\ldots$ & $\ldots$ & $\ldots$ & 22.4 & 23.1 & 22.7 & 22.7 \\
\hline Domestically financed expenditures $6 /$ & 25.9 & 26.0 & 23.5 & 25.5 & 27.3 & 24.7 & 24.7 \\
\hline
\end{tabular}

Sources: Djibouti authorities; and Fund staff estimates and projections.

1/ Same as the 2004 budget, except for higher project-grants and loans (equivalent to 0.7 percent of GDP) secured after the approval of the budget by the National Assembly.

2/ 2002 staff estimates.

3/ Includes severance payments to military personnel being demobilized.

4 / Includes foreign-financed military expenditure.

$5 /$ Total revenue (excluding grants) less total domestically-financed current and capital expenditures.

6/ Excludes from the wage bill the cost of demobilization which is foreign financed. 


\section{Despite limited progress made in advancing key structural reforms, economic} growth accelerated in 2003. A sharp increase in public investment and foreign direct investment (FDI) to build the oil terminal ${ }^{7}$ bolstered real GDP growth from 2.6 percent in 2002 to an estimated 3.5 percent last year-for the first time above population growth estimated at about 2.8 percent. Buoyant port activities also contributed to more rapid growth. The increase in economic activity led to higher imports and a concomitant widening of the current account balance. Despite this, the overall balance of payment is estimated to have registered a surplus due to large (unclassified) net capital inflows (Table 3 ). Inflation has remained low at about 2 percent. The Consumer Price Index based real effective exchange rate has depreciated further as a result of the weakness of the U. S. dollar in international capital markets (to which the Djibouti franc has been pegged at a fixed parity since the early 1970s under a currency board), but it remains significantly overvalued (Figure 2). ${ }^{8}$ Money demand growth continued to be very strong last year, reflecting in part an improvement in the liquidity position of households following the repayment of wage arrears (Table 4). Credit to the nongovernment sector declined for the third consecutive year - albeit at about half the 2002 rate. These developments resulted in a further buildup of net foreign assets by the banking system. On the reform front, the authorities adopted a plan to restructure the telecommunications company, and hired a foreign expert to manage and implement it.

Figure 2. Djibouti: Real Effective Exchange Rate Index, Jan. 1990-Jan. 2004

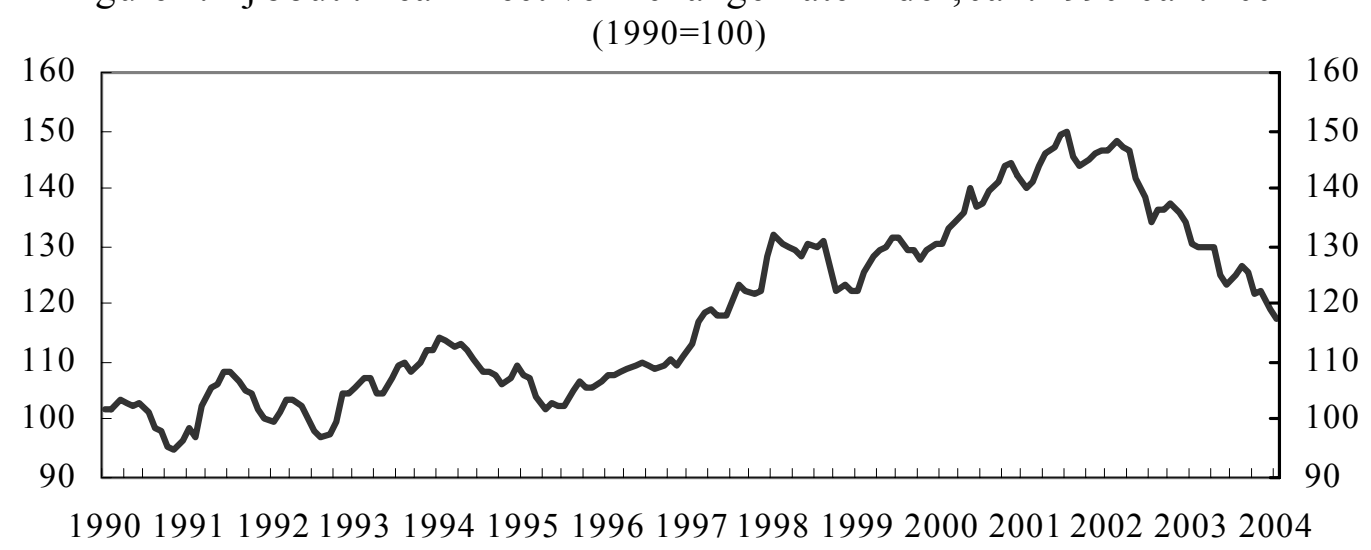

Source: IMF, Information Notice System.

\footnotetext{
${ }^{7}$ The total investment for the oil terminal is equivalent to about 10 percent of 2003 GDP, financed by the Emirate of Dubai's National Oil Company and the Dubai Port Authority, which has managed the Djibouti Port since the early 2000s.

${ }^{8}$ Despite this depreciation, the staff analysis of Djibouti's competitiveness that was presented in the 2001 Article IV consultation report remains valid.
} 
Table 3. Djibouti: Balance of Payments, 1999-2004

(In millions of U.S. dollars, unless otherwise indicated)

\begin{tabular}{|c|c|c|c|c|c|c|}
\hline & 1999 & 2000 & 2001 & 2002 & $\frac{2003}{\text { Est. }}$ & $\frac{2004}{\text { Proj. }}$ \\
\hline Current account (including grants) & -1.9 & -39.7 & -31.9 & -40.1 & -47.4 & -68.6 \\
\hline Trade balance & -182.4 & -194.8 & -187.4 & -204.1 & -249.2 & -289.2 \\
\hline $\begin{array}{l}\text { Exports, f.o.b. } \\
\text { Of which }\end{array}$ & 69.2 & 75.4 & 75.7 & 82.5 & 89.0 & 97.5 \\
\hline $\begin{array}{l}\text { Locally produced goods } \\
\text { Imports, f.o.b. } 1 /\end{array}$ & $\begin{array}{r}14.0 \\
251.7\end{array}$ & $\begin{array}{r}14.4 \\
270.3\end{array}$ & $\begin{array}{r}14.0 \\
263.1\end{array}$ & $\begin{array}{r}15.3 \\
286.6\end{array}$ & $\begin{array}{r}17.0 \\
338.2\end{array}$ & $\begin{array}{r}18.9 \\
386.7\end{array}$ \\
\hline $\begin{array}{l}\text { Services and income (net) } \\
\text { Services, net } \\
\text { Income, net 2/ }\end{array}$ & $\begin{array}{r}116.7 \\
104.5 \\
12.2\end{array}$ & $\begin{array}{r}102.0 \\
86.2 \\
15.8\end{array}$ & $\begin{array}{r}122.8 \\
110.1 \\
12.6\end{array}$ & $\begin{array}{r}123.4 \\
113.0 \\
10.4\end{array}$ & $\begin{array}{r}158.1 \\
117.2 \\
40.9\end{array}$ & $\begin{array}{r}157.6 \\
121.9 \\
35.7\end{array}$ \\
\hline $\begin{array}{l}\text { Unrequited transfers } \\
\text { Private (net) } \\
\text { Official (net) }\end{array}$ & $\begin{array}{r}62.7 \\
-5.7 \\
68.4\end{array}$ & $\begin{array}{l}53.1 \\
-6.9 \\
60.0\end{array}$ & $\begin{array}{r}32.7 \\
-5.9 \\
38.6\end{array}$ & $\begin{array}{r}40.6 \\
-3.7 \\
44.4\end{array}$ & $\begin{array}{r}43.6 \\
-3.7 \\
47.3\end{array}$ & $\begin{array}{l}63.0 \\
-3.5 \\
66.5\end{array}$ \\
\hline $\begin{array}{l}\text { Capital account } \\
\text { Foreign direct investment 3/ } \\
\text { Public sector (net) }\end{array}$ & $\begin{array}{r}-1.2 \\
4.2 \\
-5.5\end{array}$ & $\begin{array}{r}30.7 \\
3.3 \\
27.4\end{array}$ & $\begin{array}{r}10.2 \\
2.2 \\
7.9\end{array}$ & $\begin{array}{r}34.9 \\
5.0 \\
29.9\end{array}$ & $\begin{array}{l}59.7 \\
21.4 \\
38.3\end{array}$ & $\begin{array}{l}82.1 \\
63.1 \\
19.0\end{array}$ \\
\hline $\begin{array}{l}\text { Errors and omissions } \\
\text { (including unclassified net private capital flows) }\end{array}$ & 12.1 & -9.1 & 61.7 & 55.0 & 52.8 & 5.6 \\
\hline Overall balance (deficit -) & 7.9 & -18.1 & 39.9 & 49.8 & 65.2 & 19.1 \\
\hline $\begin{array}{l}\text { Financing } \\
\text { Monetary movements (increase -) } \\
\text { Central bank 4/ } \\
\text { Of which: Net disbursements from the IMF } \\
\text { Commercial banks } \\
\text { Exceptional financing }\end{array}$ & $\begin{array}{r}-7.9 \\
-15.8 \\
-1.7 \\
4.2 \\
-14.0 \\
7.9\end{array}$ & $\begin{array}{r}18.1 \\
21.3 \\
4.2 \\
1.3 \\
17.0 \\
-3.2\end{array}$ & $\begin{array}{r}-39.9 \\
-47.6 \\
-0.4 \\
-2.6 \\
-47.2 \\
7.7 \\
\text { n percen }\end{array}$ & $\begin{array}{r}-49.8 \\
-49.8 \\
-4.5 \\
-1.0 \\
-45.3 \\
0.0 \\
\end{array}$ & $\begin{array}{r}-65.2 \\
-77.7 \\
-26.3 \\
-0.4 \\
-51.4 \\
12.6\end{array}$ & $\begin{array}{r}-19.1 \\
-19.1 \\
-6.0 \\
-0.3 \\
-13.1 \\
0.0\end{array}$ \\
\hline $\begin{array}{l}\text { Memorandum items } \\
\text { Current account } \\
\text { Capital account 5/ } \\
\text { Overall balance }\end{array}$ & $\begin{array}{r}-0.6 \\
2.0 \\
1.5\end{array}$ & $\begin{array}{r}-7.2 \\
3.9 \\
-3.3\end{array}$ & $\begin{array}{r}-5.6 \\
13.4 \\
2.9\end{array}$ & $\begin{array}{r}-6.8 \\
15.2 \\
8.4\end{array}$ & $\begin{array}{l}-7.6 \\
18.0 \\
10.4\end{array}$ & $\begin{array}{r}-10.3 \\
13.2 \\
2.9\end{array}$ \\
\hline $\begin{array}{l}\text { Central bank gross foreign assets } \\
\text { In months of imports } 6 /\end{array}$ & $\begin{array}{r}70.4 \\
3.2\end{array}$ & $\begin{array}{r}67.6 \\
2.9\end{array}$ & $\begin{array}{r}70.3 \\
3.1\end{array}$ & $\begin{array}{r}74.5 \\
3.1\end{array}$ & $\begin{array}{r}100.9 \\
3.5\end{array}$ & $\begin{array}{r}106.2 \\
3.2\end{array}$ \\
\hline $\begin{array}{l}\text { Official external debt } \\
\text { In millions of U.S. dollars } \\
\text { In percent of GDP }\end{array}$ & $\begin{array}{r}336.9 \\
62.8\end{array}$ & $\begin{array}{r}369.9 \\
66.9\end{array}$ & $\begin{array}{r}373.7 \\
65.2\end{array}$ & $\begin{array}{r}395.3 \\
66.8\end{array}$ & $\begin{array}{r}426.5 \\
68.3\end{array}$ & $\begin{array}{r}448.0 \\
67.5\end{array}$ \\
\hline Nominal GDP (in millions of U.S. dollars) & 536 & 553 & 574 & 592 & 625 & 664 \\
\hline
\end{tabular}

Sources: Djibouti authorities; and Fund staff estimates and projections.

$1 /$ The increase in imports during the projection period reflects rising investment on the oil terminal and the port facility.

$2 /$ Includes the U.S. rent of military base and the French tax compensation.

3/ Reflects FDI on oil terminal and new port facility.

4/ Excluding disbursements from the IMF and AMF in 2001 and 2002.

$5 /$ Including errors and omissions.

6/ Imports of goods for domestic use and nonfactor services. 
Table 4. Djibouti: Monetary Survey, 1999-2004

(In millions of Djibouti francs)

\begin{tabular}{|c|c|c|c|c|c|c|}
\hline & 1999 & 2000 & 2001 & 2002 & 2003 & $\frac{2004}{\text { Proj. }}$ \\
\hline Broad money & 52,021 & 52,608 & 56,569 & 65,437 & 77,057 & 80,920 \\
\hline Currency in circulation & 9,289 & 9,207 & 9,370 & 10,188 & 11,113 & 11,803 \\
\hline Deposits & 42,732 & 43,401 & 47,199 & 55,249 & 65,944 & 69,117 \\
\hline Demand deposits & 20,986 & 18,704 & 19,275 & 25,327 & 31,737 & 33,264 \\
\hline Djibouti francs & 13,253 & 13,273 & 13,688 & 16,304 & 21,072 & 22,086 \\
\hline Foreign currency & 7,733 & 5,431 & 5,587 & 9,023 & 10,665 & 11,178 \\
\hline Time deposits & 21,746 & 24,697 & 27,924 & 29,922 & 34,207 & 35,853 \\
\hline Djibouti francs & 3,578 & 4,801 & 7,161 & 8,820 & 11,765 & 12,331 \\
\hline Foreign currency & 18,168 & 19,896 & 20,763 & 21,102 & 22,442 & 23,522 \\
\hline Net foreign assets & 33,725 & 29,945 & 38,412 & 47,269 & 59,952 & 63,344 \\
\hline Central bank & 10,097 & 9,346 & 9,425 & 10,238 & 13,780 & 14,842 \\
\hline Assets & 12,508 & 12,013 & 12,496 & 13,245 & 17,940 & 18,878 \\
\hline Liabilities & 2,411 & 2,667 & 3,071 & 3,012 & 4,165 & 4,036 \\
\hline Commercial banks & 23,628 & 20,599 & 28,987 & 37,031 & 46,172 & 48,502 \\
\hline Assets & 31,679 & 29,507 & 35,873 & 44,681 & 52,636 & 55,031 \\
\hline Liabilities & 8,051 & 8,908 & 6,886 & 7,650 & 6,464 & 6,529 \\
\hline Net domestic assets & 18,296 & 22,663 & 18,157 & 18,168 & 17,105 & 17,577 \\
\hline Claims on government (net) & 1,757 & 2,402 & 2,959 & 4,537 & 4,845 & 4,526 \\
\hline Central bank & 1,776 & 2,378 & 2,916 & 3,062 & 3,539 & 3,408 \\
\hline Commercial banks & -19 & 24 & 43 & 1,475 & 1,306 & 1,119 \\
\hline Claims on nongovernment sector & 30,251 & 32,953 & 28,656 & 27,003 & 26,226 & 27,016 \\
\hline Public enterprises & 2,309 & 1,540 & 1,758 & 1,374 & 1,259 & 1,297 \\
\hline Private sector & 27,942 & 31,413 & 26,898 & 25,629 & 24,967 & 25,719 \\
\hline Of which: In foreign currency & 7,912 & 11,014 & 6,522 & 6,375 & 6,801 & 7,006 \\
\hline Capital accounts & $-11,267$ & $-10,263$ & $-10,432$ & $-10,483$ & $-10,477$ & $-10,477$ \\
\hline \multirow[t]{2}{*}{ Other items (net) } & $-2,445$ & $-2,429$ & $-3,026$ & $-2,889$ & $-3,489$ & $-3,489$ \\
\hline & \multicolumn{6}{|c|}{ (Change from preceding December; in percent of broad money) } \\
\hline Broad money & 5.2 & 1.1 & 7.5 & 15.7 & 17.8 & 5.0 \\
\hline Currency in circulation & 0.4 & -0.2 & 0.3 & 1.4 & 1.4 & 0.9 \\
\hline Demand deposits & 4.0 & -4.4 & 1.1 & 10.7 & 11.3 & 2.0 \\
\hline Time deposits & 0.7 & 5.7 & 6.1 & 3.5 & 7.6 & 2.1 \\
\hline Net foreign assets & 5.7 & -7.3 & 16.1 & 15.7 & 19.4 & 4.4 \\
\hline Central bank & 0.6 & -1.4 & 0.2 & 1.4 & 5.4 & 1.4 \\
\hline Commercial banks & 5.0 & -5.8 & 15.9 & 14.2 & 14.0 & 3.0 \\
\hline Net domestic assets & -0.5 & 8.4 & -8.6 & 0.0 & -1.6 & 0.6 \\
\hline Claims on government (net) & -0.2 & 1.2 & 1.1 & 2.8 & 0.5 & -0.4 \\
\hline Claims on nongovernment sector & 2.7 & 5.2 & -8.2 & -2.9 & -1.2 & 1.0 \\
\hline Capital accounts & -2.2 & 1.9 & -0.3 & -0.1 & 0.0 & 0.0 \\
\hline Other items (net) & -0.9 & 0.0 & -1.1 & 0.3 & -0.9 & 0.0 \\
\hline \multicolumn{7}{|l|}{ Memorandum items } \\
\hline Credit to nongovernment sector (annual & & & & & & \\
\hline change in percent & 4.6 & 8.9 & -13.0 & -5.8 & -2.9 & 3.0 \\
\hline Net international reserves (in millions of U.S. dollars) & 7.5 & 8.7 & 9.5 & 9.6 & 12.2 & 12.2 \\
\hline
\end{tabular}

Sources: Djibouti authorities; and Fund staff projections. 


\section{B. Developments in early 2004}

\section{Preliminary data suggest that fiscal consolidation continued during the first} quarter of 2004. The domestic fiscal balance recorded a surplus through March of DF 1.3 billion (equivalent to about 1.1 percent of 2004 GDP), on account of the disbursement of the defense-related receipts from France and the United States. Excluding these receipts, the domestic fiscal deficit also improved, declining by 13 percent in nominal terms relative to the same quarter in 2003 (or by about 0.3 percent of GDP). This improvement mainly reflected expenditure restraint (with domestically financed spending falling by 0.8 percent in nominal terms, notably transfers and maintenance), and higher domestic revenue (up 2.5 percent) boosted by strong activity of the port and construction.

\section{The authorities met nine out of the fourteen end-March 2004 indicative targets} under the SMP. All four fiscal targets were met. The improved monitoring of budgetary allocation appears to be paying off, as the ceilings on the wage bill and expenditures on goods, services, and transfers were met (Table 5). Moreover, the early disbursement of defense-related receipts allowed for a much larger-than-programmed increase in government revenue as well as net reduction in the stock of domestic arrears, which fell by about DF 1 billion on account of repayment of arrears on wages and to private sector suppliers. The data also indicate that the authorities devoted some resources to repaying overdue external debt. In addition, public enterprises made a net repayment by-end March 2004 of about DF 202 million in external payment arrears (no net repayment was envisaged in the SMP). The authorities also met the targets on government borrowing from public enterprises and nonconcessional external debt.

\section{End-March 2004 indicative targets on monetary indicators and accumulation of} new external arrears were, however, missed. Net credit to the government by both the central and commercial banks was slightly above the targets, and net international reserves were below the target. The authorities indicated that net central bank credit to government was higher than programmed because of the larger-than-expected drawdown in government deposits at the central bank to service the external debt. The decline in net international reserves mainly reflected an unexpected fall in other liabilities of the central bank. ${ }^{9,10}$ The central government accumulated about DF 90 million in new external arrears by end-March,

${ }^{9}$ Given Djibouti's currency board, net international reserves are defined as the excess of net foreign assets over all domestic monetary liabilities of the Central Bank of Djibouti (see Annex IV of Attachment II for further details).

${ }^{10}$ End-March 2004 monetary data showed that broad money grew by almost 16 percent from a year earlier, with net foreign assets rising by 19 percent and net domestic assets declining by about 3 percent. This decline was due to a drop in credit to the government of about 13 percent and to the nongovernment sector by 2 percent from a year earlier. 
Table 5. Djibouti: Indicative Targets, End-March 2004 1/

(In millions of Djibouti francs, unless otherwise stated)

\begin{tabular}{|c|c|c|c|c|}
\hline & & \multirow{2}{*}{$\frac{2003}{\underline{\text { Prel. }}}$} & \multicolumn{2}{|c|}{$\begin{array}{l}\text { Cumulative flows from } \\
\text { January } 2004 \\
\text { (Unless stated otherwise) } \\
\end{array}$} \\
\hline & & & $\begin{array}{r}\text { Proj. } \\
\text { Mar. 31 }\end{array}$ & $\begin{array}{r}\text { Prov. } \\
\text { Mar. } 31\end{array}$ \\
\hline 1. & Ceiling on the wage bill $2 /$ & 15,819 & 4,200 & 3,932 \\
\hline 2. & $\begin{array}{l}\text { Ceiling on outstanding domestic arrears at end of period 3/ } \\
\text { Ceiling on external arrears } \\
\text { Government } 4 /\end{array}$ & 26,170 & 26,000 & 25,174 \\
\hline 3. & Outstanding at end of period 5/ & 1,193 & 1,193 & 1,175 \\
\hline 4. & $\begin{array}{l}\text { New 1/ 6/ } \\
\text { Public enterprises 4/ }\end{array}$ & & 0 & 90 \\
\hline 5. & Outstanding at end of period 5/ & 2,650 & 2,650 & 2,448 \\
\hline 6. & New $1 / 7 /$ & 0 & 0 & 521 \\
\hline 7. & Ceiling on net central bank credit to the government $2 /$ & 476 & -64 & 48 \\
\hline 8. & Ceiling on net commercial banks credit to the government $2 /$ & -169 & -91.9 & -78 \\
\hline 9. & $\begin{array}{l}\text { Ceiling on government borrowing from public enterprises } \\
\text { Ceiling on nonconcessional external debt with a maturity of } \\
\text { more than one year (except commercial credits) contracted or } \\
\text { backed by: }\end{array}$ & -96 & -48 & -48 \\
\hline 10. & The government & & 0 & 0 \\
\hline 11. & Public enterprises & & 0 & 0 \\
\hline 12. & Floor on fiscal revenue $2 /$ & 31,220 & 6,100 & 8,376 \\
\hline 13. & Ceiling on expenditure on goods, services and transfers $2 / 8$ / & 11,378 & 3,200 & 2,901 \\
\hline 14. & $\begin{array}{l}\text { Floor on net international reserves (in millions of U.S. } \\
\text { dollars) }\end{array}$ & 12.2 & 10.0 & 9.1 \\
\hline Men & norandum items & & & \\
\hline & Total external budgetary aid 2/9/ & 2,239 & 0 & 0 \\
\hline & Loans 10/ & 889 & 0 & 0 \\
\hline & Grants & 1,350 & 0 & 0 \\
\hline
\end{tabular}

1/ See Attachment II, Annex IV, for a definition of indicative targets.

2/ Cumulative flows from beginning of the year.

3 / If the net external budgetary financing flows are lower (higher) than the programmed amounts, the targets set for arrears repayment will be adjusted downward (upward) by the amount of the shortfall (excess).

4/ The ceilings or targets will be lowered by the amount that might be obtained through debt rescheduling or cancellation.

5/ All subsequent upward (downward) revisions of this amount due to improvement in the data will cause an upward (downward) adjustment of the ceilings and targets in each subsequent period.

6/ DF 35 million of the total accumulation of new arrears by end-March are toward Spain.

7/ The accumulation of new arrears corresponds to the debt service of a credit from Italy.

8/ Includes transfers related to peace agreements.

9/ External loans and grants concerned are solely those that are fungible and exclude all loans and grants under the investment program.

10/ Excluding the IMF and AMF. 
in part due to temporary administrative delays. Indeed, DF 55 million of the DF 90 million have been repaid since then, while the reminder corresponds to the debt service vis-à-vis Spain. Public enterprises also accumulated new external payment arrears by end-March 2004 vis-à-vis Italy. In this context, the staff welcomed the authorities' intention (as indicated in the MEFP) to resume contact with Paris Club members in the course of 2004 to normalize relations.

9. The authorities confirmed that the prior actions have been implemented broadly as envisaged in the SMP (Appendix II). These included measures to implement the retirement and demobilization programs and increase transparency. They explained that the $\$ 4.75$ million received from the United States in October 2002 (the first payment for the rent of a military base) was used to construct a new camp for the Djibouti army, which previously occupied the camp currently rented to the United States. However, the first phase of the demobilization program covered 240 ex-combatants, 10 less than expected under the prior actions. In addition, the decree reorganizing the ministry of finance- the end-March structural benchmark - was only adopted in early May. On other developments, following the recent receipt of the auditor's certification of the 2002 central bank accounts, the authorities have decided to publish shortly these accounts in the Journal Officiel.

\section{Policy Discussions}

10. Consistent with Board recommendations at the time of the last Article IV consultation, the measures envisaged under the SMP should help the authorities reestablish their credibility and demonstrate their commitment to policy reforms (Box 1). In this context, the authorities intend to further strengthen the fiscal position, reduce domestic arrears - in line with a 10-year reduction program agreed at the end of the previous PRGF arrangement and reconfirmed by a presidential decree in September 2003 - and complete the unfinished reform agenda of the previous PRGF arrangement. Annex III of Attachment II outlines in detail the policy measures that the authorities plan to adopt under the SMP.

\section{A. The Macroeconomic Framework and Policies}

\section{Maintaining a stable macroeconomic environment is one of the main objectives} of the SMP. The domestic fiscal surplus is targeted to rise by 1.3 percent of GDP to 2.1 percent under the program (see table below). Excluding defense-related receipts from France and the United States, the domestic fiscal deficit is expected to decline to 2.1 percent of GDP in 2004 from an estimated 4.2 percent in 2003. This improvement is needed for the government to pay off its domestic budgetary arrears under the current 10-year plan to clear these arrears, and to meet its scheduled repayment obligations on domestic and foreign debt, without adding to its high debt level. In addition, the overall fiscal balance (on a paymentorder basis) is projected to record a surplus of close to 1 percent of GDP in 2004-a prudent stance in light of the current uncertainty regarding payments by the United States for the rent 


\section{Box 1. Djibouti: 2003 Article IV Consultation-Main Policy Recommendations}

At the conclusion of the 2003 Article IV consultation on January 7, 2004, Executive Directors considered that macroeconomic performance and progress in implementing reforms during the 1999-2002 PRGF arrangement were mixed despite the restoration of some degree of fiscal discipline and adoption of reforms. They consider that the authorities face important challenges. In particular, to put economic growth on a higher and sustained path, Directors urged the authorities to support private sector development by strengthening Djibouti's external competitiveness through financial stability and reforms, to reduce high labor costs, and improve the regulatory environment for private activity. Directors, however, expressed a wide range of views about the desirability of an action on the exchange rate to improve the country's competitiveness. Some Directors considered that a carefully considered realignment of the exchange rate at an appropriate time should not be ruled out as one element of an overall policy package of structural reforms. Given the narrow production base of Djibouti's economy, a number of Directors felt that the restoration of competitiveness would be better pursued through a focused and decisive effort to address the structural rigidities in the economy.

On fiscal policy, Directors considered that the large additional revenue from the foreign military now stationed in Djibouti should provide ample room to increase social expenditures and repay domestic debt. In this context, they urged the authorities to alter the allocations in favor of higher and well-targeted expenditures in priority sectors, to reduce the wage bill by pursuing the demobilization program, better control the usage of utilities, and reduce nonessential expenditures on goods and services. Directors noted that repaying domestic arrears equitably and according to transparent priorities would greatly contribute to restoring the government's financial credibility. Further progress should be made to integrate the functions of tax management, control, and collection to support the introduction of a value-added tax (VAT) in early 2006, as currently planned. Directors also encouraged the authorities to further enhance the transparency of public finances.

On financial sector reforms, Directors welcomed the authorities' strategy to develop microfinance institutions. Priorities for the period ahead should be the adoption of the revised banking law and central bank statutes, the strengthening of the banking supervision capacity of the central bank, and more frequent inspections of financial institutions.

On other policy recommendations, Directors urged the authorities to fully normalize their relations with donors and settle all remaining external arrears. To address statistical weaknesses, Directors encouraged the authorities to forcefully implement the recommendations of the various Fund technical assistance missions, and to consider participation in the Fund's General Data Dissemination System (GDDS). 
of a military base over the medium term as the contract is expected to be renegotiated toward the end of 2004. An annual budget in line with the program was approved by the National Assembly at end-December 2003. ${ }^{11}$

\section{Djibouti: Sources and Uses of Fiscal Resources}

(In percent of GDP)

\begin{tabular}{lccc}
\hline & & Est. & Proj. \\
\cline { 3 - 4 } & 2002 & 2003 & 2004 \\
\hline Sources (total): & 1.3 & 3.1 & 2.5 \\
$\quad$ Domestic fiscal balance: & -2.0 & 0.8 & 2.1 \\
$\quad$ Of which & & & \\
$\quad$ Military-related receipts & 1.1 & 5.0 & 4.2 \\
$\quad$ Non-earmarked budgetary grants and loans & 1.8 & 2.0 & 0.8 \\
$\quad$ Net domestic financing & 1.5 & 0.2 & -0.4 \\
Uses (total) & 1.3 & 3.1 & 2.5 \\
$\quad$ Payment of domestic and external arrears & 0.7 & 2.7 & 1.8 \\
$\quad$ Amortization of external loans & 0.6 & 0.4 & 0.7 \\
Memorandum item & & & \\
$\quad$ Domestic fiscal balance & & & \\
$\quad$ (excluding military-related receipts) & -3.1 & -4.2 & -2.1 \\
\hline
\end{tabular}

Sources: National authorities; and Fund staff estimates and projections.

\section{The targeted improvement in the domestic fiscal balance, especially excluding} defense-related receipts, looks ambitious but achievable. Domestically financed expenditures will be reduced by 2.6 percent of GDP owing to cuts in wages and salaries, spending on goods and services, and public investment. These cuts should be feasible if one takes into account that the cost incurred last year in establishing two new public enterprises

\footnotetext{
${ }^{11}$ Since the approval of the 2004 budget by the National Assembly, the authorities have secured the equivalent to 0.7 percent of GDP in additional external project financing in the form of grants and loans. These additional resources are reflected in the 2004 staff fiscal projections.
} 
and paying the one-off nature of the back-payment to teachers (which together totaled about 1 percent of GDP) will not be repeated in 2004. Moreover, the wage bill is budgeted to remain about constant in nominal terms (albeit declining by 0.7 percent of GDP), with increases in recruitment in priority sectors largely offset by savings from the resumption of the retirement and the demobilization programs. The budgeted decline in domestically financed spending as a share of GDP will more than offset the envisaged fall in domestic revenue equivalent to 1.3 percent of GDP, as the one-off payment from the United States in 2003 is not expected to be repeated this year. Other domestic revenues (excluding defense-related receipts) are expected to increase by 4.3 percent in nominal terms from a year earlier, despite some initial loss in revenue from the reduction in the consumption tax on selected imports (such as computers) to encourage domestic activity and lessen the incentive for tax evasion.

\section{The 2004 budget reflects a more focused approach on poverty and growth.}

Investment in education, health, and other social sectors accounts for close to 60 percent of total public investment this year, and investment in infrastructure and housing for 20 percent. In particular, investment in school and health infrastructure, rural water schemes and wells, as well as rural livestock and fishing support are expected to improve the living standards and income of the rural communities, where indigent poverty affects 96 percent of the population (Table 6).

\section{Another important macroeconomic goal for 2004 is to achieve a real GDP} growth of about 4 percent, or slightly above 1 percent in per capita terms. This increase is mainly predicated on a sharp rise in private sector investment from about 9 percent of GDP in 2003 to 14 percent in 2004 as a result of the construction of the oil pipeline, the new container port complex, and the associated free zone. ${ }^{12}$ Inflation is projected at about 2 percent. Higher investment is likely to result in rapidly rising imports, and a deterioration in the external current account deficit. Nonetheless, the overall balance of payments is expected to record a surplus for the fourth consecutive year, owing to rising FDI and other net capital inflows. Meanwhile, monetary policy will continue to be pursued in a manner consistent with the currency board.

15. Djibouti is not expected to face an external financing gap in 2004. The authorities have budgeted to receive the equivalent of about 1 percent of GDP as nonearmarked grantsabout the average level received in the period 2000-03. The staff had extensive discussions with the donor community about the SMP, which, in general, favored the adoption of such a

\footnotetext{
12 Some 20 to 30 foreign private sector operators from mainly the Emirate of Dubai are expected to start operations shortly in the free zone. The cabinet recently approved a free zone law.
} 
Table 6. Djibouti: Millennium Development Goals, 1990-2015

\begin{tabular}{lllll}
\hline Target \\
2015 \\
\hline
\end{tabular}

\section{Goal 1. Eradicate extreme poverty and hunger}

Target 1: Halve, between 1990 and 2015, the proportion of people whose income is less than one dollar a day.

1. Population below $\$ 1$ a day (in percent)

2. Poverty gap at $\$ 1$ a day (in percent)

3. Percentage share of income or consumption held by poorest 20 percent

Target 2: Halve, between 1990 and 2015, the proportion of people suffering from hunger.

4. Prevalence of child malnutrition (percent of children under 5)

5. Population below minimum level of dietary energy consumption (percent)

\section{Goal 2. Achieve universal primary education}

Target 3: Ensure that, by 2015, children everywhere, boys and girls alike, will be able to complete a full course of primary schooling.

6. Net primary enrollment ratio (percent of relevant age group)

7. Percentage of cohort reaching grade 5 (percent)

8. Youth literacy rate (percent ages 15-24)

$\begin{array}{ccc}32.2 & 32.6 & \ldots \\ 79 & \ldots & \ldots \\ 79 & 84.9 & 85.7\end{array}$

\section{Goal 3. Promote gender equality}

Target 4: Eliminate gender disparity in primary and secondary education preferably by 2005 and to all levels of education no later than 2015 .

9. Ratio of girls to boys in primary and secondary education (percent)

10. Ratio of young literate females to males (percent ages 15-24)

11. Share of women employed in the nonagricultural sector (percent)

12. Proportion of seats held by women in national parliament (percent)

\section{Goal 4. Reduce child mortality}

Target 5: Reduce by two-thirds, between 1990 and 2015, the under-five mortality rate.

13. Under 5 mortality rate (per 1,000)

$\begin{array}{cccc}70.4 & 73.2 & 85.3 & \ldots \\ 78.1 & 84.4 & 90.4 & 91.2 \\ \ldots & \ldots & \ldots & \ldots \\ \ldots & \ldots & \ldots & \ldots \\ & & & \\ & & & \\ & & & \\ 175 & 160 & 143 & 141 \\ 119 & 111 & 100 & 99 \\ 85 & 41 & 49 & \ldots\end{array}$

14. Infant mortality rate (per 1,000 live births)

15. Immunization, measles (percent of children under 12 months)

\section{Goal 5. Improve maternal health}

Target 6: Reduce by three-quarters, between 1990 and 2015, the maternal mortality ratio.

16. Maternal mortality ratio (modeled estimate, per 100,000 live births)

17. Proportion of births attended by skilled health staff

\section{Goal 6. Combat HIV/AIDS, malaria and other diseases}

Target 7: Halt by 2015, and begun to reverse the spread of HIV/AIDS, the incidence of malaria and other major diseases.

18. Prevalence of HIV, female (percent ages 15-24)

19. Contraceptive prevalence rate (percent of women ages 15-49)

20. Number of children orphaned by HIV/AIDS

$\begin{array}{cccc}\ldots & 520 & \cdots & \cdots \\ \cdots & \cdots & \cdots & \cdots\end{array}$


Table 6. Djibouti: Millennium Development Goals, 1990-2015 (concluded)

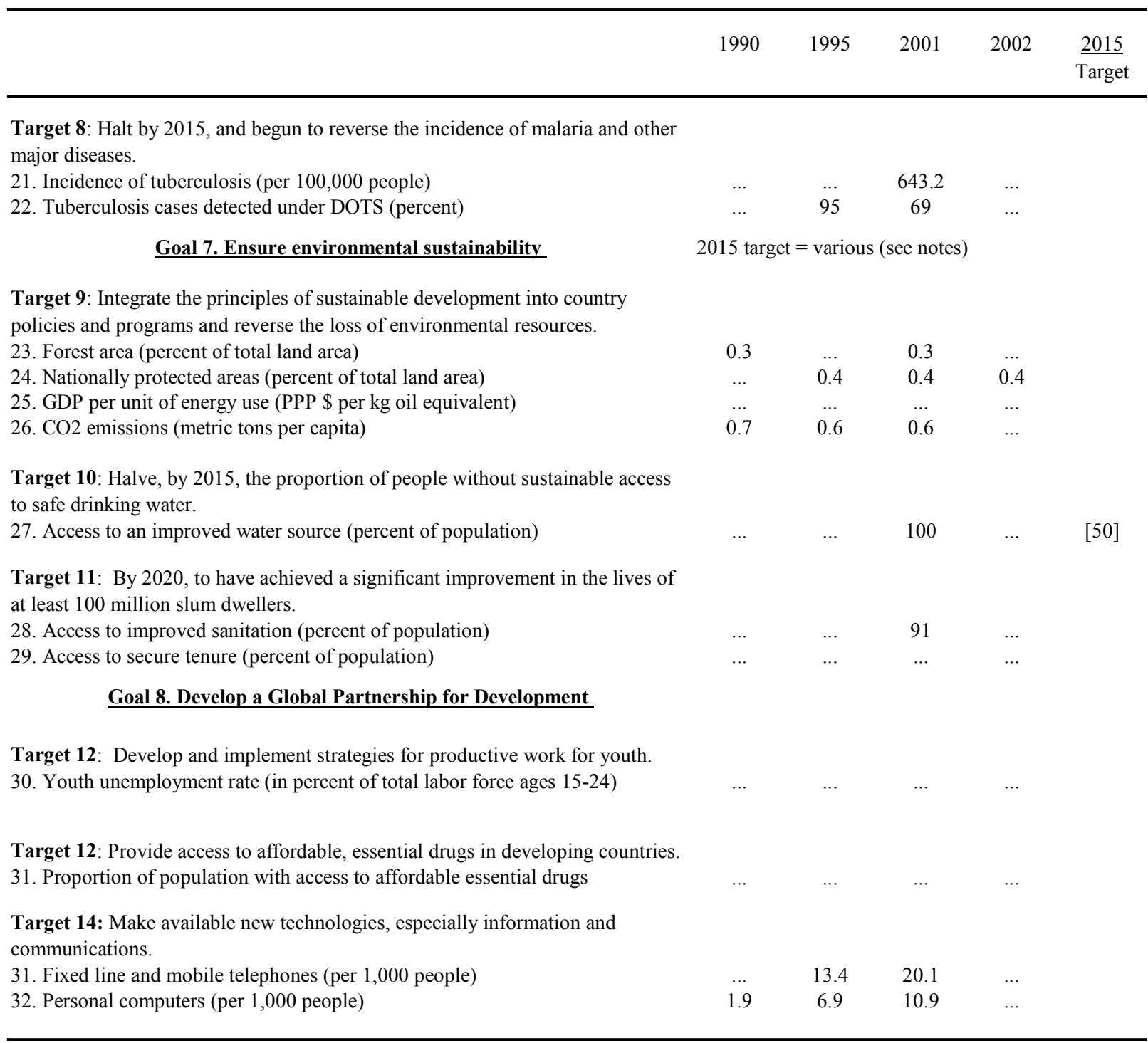

Source: World Bank, World Development Indicators database, April 2002. 
program, particularly as an adequate framework for government policy coordination.

However, key donors indicated that the absence of a Fund arrangement and a relatively long internal procedure of approval preclude them from disbursing these grants in 2004. The loss of this aid will most probably result in a lower reduction in domestic arrears (budgeted at 1.8 percent of GDP), as the authorities expected that donors will share the burden of reducing these arrears - a large part of them accumulated during the civil conflict in the early 1990s.

\section{B. Structural Reforms}

\section{Another key objective of the SMP is to complete the unfinished reform agenda} under the previous PRGF arrangement. These long-overdue reforms are essential to improve competitiveness, restore confidence, and promote private sector development. Their adoption merely requires a political decision and is not expected to strain the country's administrative capacity. Regarding fiscal reforms, the authorities intend to further improve spending efficiency and strengthen the institutions responsible for formulating, executing, and monitoring the budget. To this end, they recently made fully effective the reorganization of the ministry of finance approved at end-2002 — a first step required to adopt a VAT by early 2006 - and plan to adopt a single computerized registry of civil servants as well as computerize tax administration. Moreover, the public expenditure review conducted by the World Bank and the Djibouti authorities in early 2004 should provide a good basis to determine shortcomings and options for reform in public expenditure management in the period ahead, including the strengthening of social safety nets with assistance from the World Bank.

\section{A number of structural measures to be implemented under the SMP seek to} improve the country's competitiveness. The authorities intend to adopt a new labor code to enhance market flexibility and reduce labor cost. A new investment code will simplify tax exemptions, streamline procedures, and attract FDI. With assistance from the World Bank, the authorities are working on a plan to restructure the power and water sectors to reduce cost over the medium term. In the external sector, the authorities intend to make progress in normalizing relations with bilateral donors to settle disputes about accumulated payment arrears. ${ }^{13}$ The authorities also plan to promote good governance and transparency to improve accountability (see Attachment II, Annex III).

18. The financial sector will be further strengthened under the SMP. The priorities will be to adopt the revised banking law and central bank statutes (a structural benchmark), to further strengthen banking supervision (the Fund has been provided regular technical assistance to the central bank in this area since end-2002), and to prepare a microfinance

\footnotetext{
${ }^{13}$ The authorities indicated that at end-2003, the stock of external arrears (central government and public enterprises) reached \$21.6 million (equivalent to about 3.5 percent of GDP).
} 
strategy to enhance development of small-size enterprises. The central bank authorities reiterated their commitment to publish the bank's annual audited financial statements. These audits will continue to be carried out by a reputable international firm.

\section{Despite some progress in recent years, Djibouti's statistical system continues to} fall short of international standards in terms of quality, frequency, and dissemination. Although the authorities have begun to implement recommendations of various Fund technical assistance missions, the situation remains particularly critical for fiscal and real sector statistics and to a lesser extent for balance of payments statistics (Appendix V). However, the authorities' recent decision to participate in the Fund's GDDS will provide an appropriate framework for the development of its statistical system and coordination of technical assistance in this area.

\section{Program Risks AND Monitoring}

20. There are risks associated with the SMP. Djibouti's record of policy implementation in previous programs has been weak. With regional elections scheduled for end-2004 and presidential elections for April 2005, expenditures may turn out to be higher than budgeted in 2004, as was the case in previous election years. A slowdown in FDI inflows (to finance the expansion of the port complex) could hurt the country's growth prospects, and delay in implementing policy reforms could jeopardize improvement in competitiveness. It is also possible that nonearmarked budgetary grants could turn out lower than anticipated.

21. In light of these risks, the staff will closely monitor program implementation. To this end, the authorities agreed to use quarterly indicative targets and structural benchmarks, as well as to conduct quarterly reviews. The indicators targeted for the period end-March to end-December 2004 will be the same as those under the previous PRGF arrangement, including a ceiling on the wage bill and a floor on domestic revenue (Attachment II, Annex I). ${ }^{14}$ In addition, given their sharp increase over the past two years, the program will include a ceiling on spending on goods, services, and transfers. Thus, the domestic fiscal balance (including and excluding defense-related receipts) will be closely monitored under the SMP. The Fund staff will also monitor structural benchmarks in the fiscal and financial sectors and in other areas that will likely contribute to improving the country's competitiveness (Attachment II, Annex II).

\footnotetext{
${ }^{14}$ The first review under the SMP is expected to take place in early September 2004 and will assess performance during the period March 31-June 30, 2004.
} 


\section{Staff ApPraisal}

22. Djibouti faces important challenges to reduce widespread poverty. Since the mid-1990s, the government has been engaged in adjustment and reform programs to restore macroeconomic stability and achieve sustainable economic growth. However, the results have been mixed due to a combination of external and internal factors, resulting in a poor track record of policy reforms.

23. The staff welcomes the authorities' intention to implement a one-year SMP. Key goals of the program are to establish a strong track record of policy reforms and improve the country's competitiveness within the current exchange rate regime. If successfully implemented, the program should contribute to enhancing growth prospects, and lay the foundation for an envisaged successor PRGF arrangement with full donors' support.

\section{The strengthening of the fiscal position is key to achieving the goals of the SMP.}

The targeted increase in the domestic fiscal surplus is necessary given the objective to further reduce the stock of domestic arrears and the expected decline in exceptional revenue and foreign financing. The staff welcomes the move toward a more pro-poor and pro-growth stance of the 2004 budget by cutting nonpriority spending and controlling the wage bill, as well as compliance with all end-March 2004 indicative fiscal targets. The staff urges the authorities to further improve spending efficiency and strengthen institutions responsible for formulating, executing, and monitoring the budget. The non-observance of the end-March 2004 indicative monetary targets call for improved monitoring from the central bank and coordination with the ministry of finance. In addition, the authorities should strengthen administrative procedures to avoid the accumulation of new external arrears in the future in line with the program's objectives. Furthermore, the staff strongly recommends early negotiations to normalize relations with bilateral donors.

\section{Long-overdue structural reforms are essential to improve the country's}

competitiveness. The adoption of the new labor code should contribute to market flexibility and thereby lower labor costs. The new investment code should simplify tax exemptions and procedures as well as promote private investment. Moreover, the staff welcomes the authorities' decision to formulate a plan to restructure the energy and water sectors with assistance from the World Bank. However, if by the end of the program, there is ample evidence that labor and other costs have not come down and overall competitiveness improved, the authorities should be ready to adopt additional measures.

26. Making progress in promoting good governance and transparency is also an important objective of the SMP. To this end, publications of the reports by the Chamber of Accounts and Fiscal Discipline, and publications on priority social spending should contribute to strengthening accountability. On the financial sector, the staff welcomes the planned adoption of a revised banking legislation and central bank charter as well as of an appropriate regulatory framework for microfinance institutions, including regular supervision 
by the central bank of their activities. The staff also welcomes the authorities' decision to publish the 2002 central bank's annual audited financial statements in the Journal Officiel.

\section{The proposed policies and reforms should be sufficient to achieve the SMP's} objectives. The staff hopes that donors will support the program with the envisaged level of budgetary nonearmarked grants to reduce domestic payment arrears even in the absence of a Fund arrangement.

\section{Overall, the program will test the authorities' resolve to implement policy}

reforms. Steps have been taken as part of prior actions to control the wage bill and improve transparency. Nevertheless, in light of weak program implementation in the past, the noncompliance with some end-March 2004 indicative targets, and upcoming regional and presidential elections, the risks and challenges to the SMP are high. Fund staff will closely monitor performance under the program, using quarterly reviews, indicative targets, and structural benchmarks in the fiscal and financial sectors as well as in other key areas that are likely to improving the country's competitiveness. 


\section{DJibouti: Performance under Previous Fund-Supported Programs}

1. Since 1978 when it became a member of the IMF, Djibouti has had two Fundsupported programs: a Stand-By Arrangement (SBA) from April 1996 to March 1999, and a three-year Poverty Reduction and Growth Facility (PRGF) arrangement, approved by the Board in October 1999 and later extended to January 2003 to allow for completion of the third and last review. Performance and policy implementation under both programs were mixed.

\section{Stand-by Arrangement}

2. Following the end of the 1991-94 civil war, which led to a cumulative contraction of GDP by nearly 15 percent and large fiscal deficits, the government of Djibouti formulated a medium-term economic adjustment and reform strategy with the objective of restoring macroeconomic stabilization and reviving growth. The strategy was supported by the Fund through a SBA. The main policies of the SBA included demobilization of 8,500 ex-combatants (on top of 4,000 demobilized prior to the program); civil service reform to further reduce the wage bill; reform of public enterprises; liberalization of the labor market; and strengthening of fiscal and macroeconomic management capacity and improvement in statistics. Policies were to be consistent with maintaining the currency board in place since the 1940 s.

3. Performance during the first year of the SBA was weak. The first review was concluded in May 1997 with a delay of six months, and only about half of the performance criteria were met. In contrast, implementation of the 1997 program was broadly as envisaged during the first nine months. Ahead of the December 1997 legislative elections, however, a breakdown in budgetary discipline occurred during the last quarter of the year. This, together with the new (and current) finance minister's decision to first launch an internal review of public finances, delayed the second review, which was completed after the Board waived more than half of the quantitative performance criteria. Performance under the 1998 program was satisfactory. All performance criteria for end-September were met and the third (and last) review was completed in January 1999. Nevertheless, the last (sixth) purchase was not affected because of non-observance of the performance criterion on the nonaccumulation of new domestic arrears. Cumulative purchases under the SBA amounted to SDR 7.3 million (63.5 percent of quota).

4. Despite these implementation difficulties, the Djibouti authorities succeeded under the SBA in reducing macroeconomic imbalances and implementing some structural reforms. The domestic fiscal balance moved from an average deficit of 6.2 percent of GDP in 1994-95 to a surplus of 1.2 percent in 1998, largely owing to a reduction in the wage bill. Indeed, the authorities reduced the wage bill by 7.9 percent of GDP from its peak in 1993 to 16.4 percent by 1998 on account of a 20 percent reduction of civil service staff, a 20 percent cut in nominal salaries, and the demobilization of 3,711 ex-combatants. Inflation more than halved from over 5 percent, on average, during 1993-95. The pre-program contraction in real 
GDP was stopped, but growth was anemic (0.1 percent) in 1998, and significantly below population growth. Although not all envisaged structural reforms were adopted, the authorities reinforced the banking supervision capacity of the central bank and partially liberalized the labor market by removing the specification of the minimum wage from the labor code. ${ }^{15}$

\section{PRGF-Supported Program}

5. The main purpose of the PRGF arrangement was the consolidation of fiscal adjustment achieved under the SBA and the implementation of an ambitious structural reform agenda to enhance growth prospects. The agenda included: tax, revenue administration, and budget management reforms; completion of the demobilization program; civil service reform; reorientation of budget outlays toward priority social spending; pension fund reform; banking sector reform; privatization of ownership/management of the six major public enterprises; ${ }^{16}$ price liberalization of petroleum products and grains; and legal reforms, including reforms of the labor and commercial codes and the establishment of commercial courts. As under the SBA, policies were to be consistent with the existing currency board arrangement.

6. Under the PRGF arrangement, Djibouti did not meet more than half of the quantitative and structural performance criteria, and only three of the six planned reviews were completed. The first review was concluded with a delay of six months, after waivers were granted for the nonobservance of a majority of quantitative and structural performance criteria. The second review could only be completed after corrective actions were implemented, delaying it for one year and leading to a rephasing of remaining purchases. At the time of the second review, there was also an instance of misreporting of external arrears toward a multilateral creditor (the Arab Monetary Fund), clearance of which was a prior action for the third review. As the PRGF arrangement expired soon after the completion of the third review, the last disbursement could not be made so that cumulative purchases amounted to only SDR 13.63 million (85.7 percent of quota) instead of the approved SDR 19.08 million.

7. In spite of these performance problems, some progress was made in implementing the reform agenda. On the fiscal front, the authorities improved the tax administration and simplified the structure of consumption and income taxes; set up a public finance auditor's office; reformed the pension system to ensure its financial sustainability; privatized the management of the port and the airport; and resolved part of their pending external debt issues. In addition, a new law against money laundering was adopted. However,

\footnotetext{
${ }^{15}$ The minimum monthly wage used to be DF 17,700 , equivalent to about $\$ 100$.

${ }^{16}$ Namely, the port, the airport, the national electricity utility, the urban water utility in Djibouti-Ville, and the two national telecommunications utilities (which are to be merged).
} 
due to a combination of external and internal reasons, fiscal indicators (in percent of GDP) did not improve much compared to the SBA-years and key structural reforms to address the deterioration in the country's competitiveness, such as the reforms of the labor, investment, and commerce codes, were not completed. The privatization of the electricity, water, and telecommunication companies stalled and tariffs on these utilities remained high. The demobilization of military personnel hired during the civil conflict was much slower than envisaged, and the civil service reform did not progress. As a result, the wage bill remained large (reaching 14 percent of GDP in 2002), preventing a reallocation of more resources toward poverty-reducing expenditure. In this context, average growth of real GDP in the PRGF arrangement years was more than one percentage point below the program objective (about 3 percent on average), while poverty deepened. 


\title{
REPUBLIC OF DJIBOUTI
}

\author{
MINISTER OF ECONOMY, \\ FINANCE AND PLANNING \\ RESPONSIBLE FOR PRIVATIZATION
}

No. 436/MEFPP

Djibouti, May 5, 2004

TO:

Mr. Mohsin Khan

Director

Middle East and Central

Asia Department

IMF

Dear Mr. Khan:

Regarding the prior actions for Board approval of the staff-monitored program, I am pleased to inform you of the following developments:

\section{- Demobilization}

Despite some delays, the security forces have at last provided a list of employees, validated by the demobilization office, the processing of which is in the final stages. As the latter fulfill the compensation criteria of the European Fund, they will no longer be included in the national budget.

- Retirement of government employees

Government employees (contractual and regular staff) were retired in 2004 pursuant to the administrative acts forwarded to you through the Fund's resident mission.

\section{- Publication of the report of the Chamber of Accounts}

The report of the Chamber of Accounts and Fiscal Discipline was finalized and forwarded to the President of the Republic and the President of the National 
Assembly. In addition, a copy of this report was sent by the latter to the SecretaryGeneral of the Government for publication in the Journal Officiel of the Republic of Djibouti (cf. attached letter).

\section{- Reorganization of the Ministry of Finance}

The implementing decree reorganizing the Ministry of Economy, Finance, and Planning Responsible for Privatization was adopted in the $14^{\text {th }}$ session of the Council of Ministers held on Tuesday, May 4, 2004.

These clarifications are provided with regard to the prior actions for approval by the IMF Executive Board of the Memorandum of Economic Policies.

Sincerely yours,

$/ \mathrm{s} /$

Yacin Elmi Bouh 


\section{DJIBOUTI}

Chamber of Accounts and Fiscal Discipline

Office of the Chief Clerk

Djibouti, May 2, 2004

\section{To: Secretary-General of the Government}

Our Ref.: 009/CCDB/GC/04

Subject: Publication of the General Report of the Chamber of Accounts and Fiscal Discipline.

Mr. Secretary-General:

In accordance with Article 127 of Law 122 dated April 1, 2001, the public report produced by the Chamber of Accounts and Fiscal Discipline (CCDB) must be made available to the public no later than two months following its submission to the National Assembly, at our behest.

Therefore we are pleased to send you the enclosed General Report of the CCDB for publication in the Journal Officiel [Official Gazette] of Djibouti.

Sincerely,

/s/

Mohamed Mohamoud Hachi

[stamp:] Office of the Chief Clerk, Chamber of Accounts and Fiscal Discipline

[handwritten:] May 3, 2004

456/56G

Encl.: General Report of the Chamber of Accounts and Fiscal Discipline 
Republic of Djibouti

ORIGINAL: FRENCH

Djibouti, April 24, 2004

No. 415/MEFPP

Director

Middle East and Central Asia Department

Dear Sir:

Under the Treaty of Establishment signed between the Republic of Djibouti and the United States, it was agreed that the Djibouti authorities would provide Camp Lemonnier, located in the airport zone, to the U.S. armed forces.

In exchange, the United States, in October 2002, paid $\$ 4.75$ million, which was used to construct a new camp for the Djibouti army contingent that previously occupied Camp Lemonnier.

Very truly yours,

$/ \mathrm{s} /$

Yacin Elmi Bouh

Minister of Economy, Finance and Planning, in Charge of Privatization 


\section{DJibouti: RELATIONS WITH THE FUND}

(As of March 31, 2004)

I. Membership Status: Joined: December 29, 1978; Article VIII

II. General Resources Account:

Quota

$\underline{\text { SDR million }}$

15.90

Fund holdings of currency

14.80

Percent of Quota

100.00

Reserve position in Fund

1.10

93.08

6.92

III. SDR Department:

Net cumulative allocation

$\underline{\text { SDR million }}$

1.18

0.09

Percent of Allocation

100.00

Holdings

7.42

IV. Outstanding Purchases and Loans:

PRGF arrangements

SDR million

Percent of Quota

13.63

85.72

V. Latest Financial Arrangements:

\begin{tabular}{llccc} 
Type & $\begin{array}{l}\text { Approval } \\
\text { Date }\end{array}$ & $\begin{array}{c}\text { Expiration } \\
\text { Date }\end{array}$ & $\begin{array}{c}\text { Amount } \\
\text { Approved } \\
\text { (SDR million) }\end{array}$ & $\begin{array}{c}\text { Amount } \\
\text { Drawn } \\
\text { (SDR million) }\end{array}$ \\
\hline PRGF & $10 / 18 / 1999$ & $01 / 17 / 2003$ & 19.08 & 13.63 \\
Stand-by & $04 / 15 / 1996$ & $03 / 31 / 1999$ & 8.25 & 7.27
\end{tabular}

VI. Projected Obligations to the Fund

(SDR million; based on existing use of resources and present holdings of SDRs):

\begin{tabular}{lccccc} 
& \multicolumn{5}{c}{ Forthcoming } \\
\cline { 2 - 6 } & 2004 & 2005 & 2006 & 2007 & 2008 \\
\cline { 2 - 6 } Principal & & 0.55 & 1.09 & 1.82 & 2.73 \\
Charges/Interest & $\underline{0.08}$ & $\underline{0.08}$ & $\underline{0.08}$ & $\underline{0.07}$ & $\underline{0.06}$ \\
Total & 0.08 & 0.63 & 1.17 & 1.89 & 2.79
\end{tabular}

VII. Implementation of HIPC Initiative: Not Applicable.

\section{Safeguards Assessments}

Under the Fund's safeguards assessment policy, the Central Bank of Djibouti (BCD) is subject to the transitional procedures with respect to the PRGF arrangement, which was 
approved on October 18, 1999 and expired on January 17, 2003. The transitional procedures require a review of only the BCD's external audit mechanism. This assessment determines whether the BCD publishes annual financial statements that are independently audited in accordance with internationally accepted standards.

The last external audit assessment was completed on July 24,2001 . The assessment concluded that the BCD's current external audit mechanism may not be compliant with the international auditing standards promulgated by the International Federation of Accountants, and recommendations had been made to the authorities, as reported in "Djibouti: Report on the External Audit Mechanism." In response to staff recommendations, the BCD hired, in August 2002, external auditors from Ernst \& Young to audit the 1999, 2000, and 2001 accounts. This audit was completed by year-end 2002. The 1999-2001 audited financial statements have recently been transmitted to the Fund but not yet published.

Since 2003, the BCD has had its accounts audited on a yearly basis in accordance with international auditing standards. The audit of the 2002 financial statements was completed by Ernst \& Young at end-2003, and the BCD authorities have recently decided to publish them in the Journal Officiel. The Fund has not yet received copies of the management letters for the years 1999-2002.

\section{Exchange arrangements}

Djibouti has a currency board arrangement. The Djibouti franc is pegged to the U.S. dollar at the rate of DF $177.721=\$ 1$. Djibouti maintains an exchange system that is free of restrictions on payments and transfers for all international current and capital transactions.

\section{Article IV Consultation}

Djibouti is on an annual consultation cycle. Discussions for the 2003 Article IV consultation were held in Djibouti from February 21 to March 7 and July 13 to July 20, 2003. The staff report (IMF Country Report No. 04/73), the selected issues paper (IMF Country Report No. 04/74), and the statistical appendix (IMF Country Report No. 04/75) were discussed by the Executive Board on January 7, 2004, and posted on the IMF public website, together with a Public Information Notice, on March 19, 2004.

FSAP Participation, ROSC, and OFC Assessment

Djibouti has not participated in any of the above-mentioned exercises.

\section{Technical Assistance}

FAD - Budget control and cash management of the treasury

April 2000

FAD-Direct tax reform

September 2000

FAD/MCD — Budget control and cash management of

February 2001 the treasury 
FAD - Tax administration and possible introduction of a VAT

April 2002

STA-Government finance statistics

May 2001

STA - National accounts and balance of payments

January 2002 statistics

STA-Balance of payment statistics

November 2003

MFD_Banking supervision

December 2002

MFD_Banking supervision

December 2003

\section{Resident Representative}

A resident representative has been stationed in Djibouti since October 1998. 


\section{DJIBOUTI: RELATIONS WITH THE WORLD BANK}

The World Bank (the Bank) has been more active in Djibouti since the start of the last Country Assistance Strategy (CAS) process in 1999. The CAS, developed in consultation with the government of Djibouti, was endorsed by the Executive Board in December 2000 and covers the FY2001-FY2003 period. Its strategic focus was to support the government's effort to reduce poverty by:

(i) giving priority to reversing one of the lowest rates of school enrollment in the world, addressing the deteriorated health situation, in particular in the critical area of HIV/AIDS, and promoting more direct support programs to the poor through an active public works and community service program;

(ii) reestablishing and consolidating fiscal stability and improving economic competitiveness through wage bill reduction, pension system reform, preparation of public enterprises for privatization; and

(iii) rehabilitating infrastructure and services related to the port as the main source of growth.

The assistance program under the CAS is comprised of four credits and two supplemental credits in support of these three areas:

- In the social area, the program is comprised of a school access and improvement project; a health sector development project; an HIV/AIDS, malaria and tuberculosis control project; and a public works/social development project to improve the social safety net. Implementation and results of these projects are satisfactory. The school access and improvement project will be implemented a year ahead of schedule. The gross enrolment rate has reached 50.2 percent compared to 39 percent at the start of the project in 2001 . The public works project, approved a year before the CAS' approval, has also achieved its objectives and was implemented a year ahead of schedule.

- In the area of structural reforms, the program included a Fiscal Consolidation Credit (FCC) focused on a set of interrelated reform areas critical for fiscal consolidation: (a) implementing the first phase of a medium-term program of restoring financial and budgetary discipline through actions to contain and start reducing the wage bill and strengthening expenditure management systems, including halting the build-up of domestic payment arrears, and beginning an orderly process for clearing the existing stock of such arrears; (b) implementing a reform of the main parameters of the existing pay-as-you-go pension system to improve its viability; and (c) strengthening financial management of the key public enterprises providing infrastructure services, and initiating a process leading to the liberalization and privatization of selected 
infrastructure sectors. The FCC was fully disbursed in October 2003 upon satisfactory implementation of its major components. In particular, there was substantial clearing of wage arrears. In addition, the pension funds reform included major increases in the vesting period (from 15 to 25 years) and the retirement age (from 50 to 55 years), as well as a reduction of the marginal replacement rate to 1.2 percent. The management of Djibouti airport was privatized and independent financial audits were completed in 2003 for all public companies.

- $\quad$ In support of growth, a supplemental credit was approved in 2003 that strengthened the original emergency international corridor rehabilitation credit approved a year before the CAS. The projects have helped Djibouti take advantage of Ethiopia's shift in routing its trade through Djibouti as a result of the regional conflict.

Portfolio Status. The portfolio status has strengthened and improved because of better supervision provided by the Bank Office in Sana'a in Yemen. As of December 31, 2003, IDA has approved 16 projects for Djibouti, valued at about $\$ 148.6$ million, of which 15 have been investment projects and one adjustment operation (FCC). Of the total amount, about $\$ 106.23$ million have already been disbursed. The current portfolio has five active projects valued at $\$ 77.8$ million, of which 60 percent is for health/social development projects; 27 percent for transport/infrastructure projects; and about 13 percent for education projects. The Bank approved one Institutional Development Fund grant in FY 2002 for capacity building to enhance Djibouti's debt management.

Looking ahead, the Bank is in the process of preparing a CAS update with the objective of aligning its program of strategic assistance to the full Poverty Reduction Strategy Paper (PRSP). This will include assistance along the three pillars defined in the PRSP: (a) growth and competitiveness; (b) human resource development and direct poverty alleviation; and (c) governance improvement. Preparatory analytical work for the CAS update is being done in the sectors of energy, water, and port and transport. The Bank is currently preparing a Country Financial Accountability Assessment, a Country Procurement Assessment Report, and a Public Expenditure Review.

Contact: $\quad$ Mr. Habib Fetini, Country Coordinator, 202-473-4471. 


\section{DJibOUTI: STATISTICAL ISSUES}

\section{Outstanding Statistical Issues}

8. Economic and financial statistics suffer, although unevenly, from deficiencies with regard to their quality, coverage, periodicity, timeliness, and dissemination. The situation is especially critical for the fiscal and real sectors, and to some extent for the balance of payments. These weaknesses continue to hamper policy analysis and monitoring. Statistics in Djibouti are compiled by different institutions, and data reconciliation among these sources is limited.

9. Recent developments, however, indicate an increasing awareness of the importance of statistics among government officials. In 2002, the authorities created the Directorate for Statistics and Demographic Studies (DISED) by merging the National Directorate of Statistics (DINAS) and the Central Bureau of Census in order to enhance capacity of the statistical system and efficient use of available resources. In February 2004, the authorities indicated their intention to participate in the Fund's General Data Dissemination System (GDDS).

\section{National Accounts}

10. The existing national accounts estimates follow the System of National Accounts 1968. The 1998 revision led to some improvements in the methodology of compilation. A supply side approach remains the mainstay of the compilation method and there continues to be a focus on main GDP aggregates. However, this revision fell short of correcting the serious shortcomings in Djibouti's national accounts arising from the underlying weaknesses in basic data sources and lack of resources. These factors also explain, in part, the limited progress made in implementing the January 2001 statistics (STA) mission recommendations.

\section{Prices}

11. The Consumer Price Index (CPI) is the only available measure of inflation in Djibouti. The CPI compiled by the French government for French expatriate residents in Djibouti was initially used as a proxy for a Djibouti CPI. This index, however, was not representative of the country's consumption basket. Therefore, in late 1998, the Fund staff began to track Djibouti price developments by utilizing: (a) sub-indices from the French CPI that were representative of Djibouti consumption; and (b) weights derived from a recent Djibouti household survey. The new national CPI is now considered to be the official measure of monthly price developments since April 1999. 


\section{Government Finance}

12. Although data compilation improvements were made over the past ten years, the fiscal data remains weak as does coordination among government agencies in producing internally consistent information. The coordination unit in the ministry of economy and finance (MOEF), established in July 1998 to improve data coverage and timeliness, has not yet succeeded in fulfilling its mandate in a satisfactory manner. This is due, in part, to inadequate staffing. Among the encouraging initiatives taken was the recent computerization of the treasury accounts, which will significantly improve the coverage, quality, timeliness, consolidation, and consistency of cash management data. Another encouraging step is the improvement of data on domestic budgetary arrears through the comprehensive audit of these arrears in 2002 with assistance from the European Union and the World Bank. Foreignfinanced capital expenditure and some foreign-financed current expenditures and their financing (namely grants and loans) have been reported since the 1999 budget. However, additional efforts are needed to improve the compilation of budgetary data, particularly at the institutional level. Limited progress has been made in this area as most of the May 2001 STA mission recommendations are still not implemented.

\section{Monetary Accounts}

13. To improve sectorization of monetary data, commercial banks were instructed in July 1999 to initiate a program for accurately identifying the residency status of customers and to report balance sheet data to the Banque Centrale de Djibouti (BCD) ${ }^{1}$ beginning with the end-December 1999 reporting period. The BCD initiated publication of a quarterly bulletin in 1995 and increased its periodicity to a monthly bulletin beginning in 2001 . Monetary statistics cover the central bank and the three operating commercial banks. STA recently received a request from the authorities for technical assistance in developing their monetary and financial statistics. A mission is envisaged for late 2004. In the meantime, STA is continuing to provide support to BCD counterparts through remote technical assistance.

\section{External Sectors}

14. A technical assistance mission in balance of payments statistics visited Djibouti in November 2003 to conduct a review of the progress in implementing the recommendations made by a previous mission that took place from January 20 to February 2, 2002. It concluded that the treatment of available data by the Research Department of the BCD improved significantly, but that the coverage of data is still relatively weak due to the low response rate from the private sector and insufficient cooperation from other official agencies.

\footnotetext{
${ }^{1}$ Banque Nationale de Djibouti before 2000.
} 
15. Improvements have been made regarding classification issues involving transit trade to neighboring countries, imports by the foreign military forces stationed in Djibouti, and the treatment of the rent paid by the United States for the military bases. Efforts are also under way to separate private capital flows from errors and omissions and to report balance of payments data to the IMF adhering to the standards set forth in the $5^{\text {th }}$ Edition of the Balance of Payments Manual.

16. However, further efforts have to be devoted to improving coverage, periodicity, and accuracy of international accounts data. In particular, the BCD should now start collecting information to establish Djibouti's international investment position. The customs administration needs to ameliorate collection of imports data, which still seem to significantly underestimate true levels of imports. To improve the response rate from the private sector to data inquiries from the $\mathrm{BCD}$, the law on the charter of the $\mathrm{BCD}$ needs to be amended to enable the BCD to collect and compile balance of payments and international investment position statistics, and to impose sanctions on non-compliant addressees. In addition, the response rate could possibly be improved by collecting balance of payments data on a more frequent — quarterly, rather than semi-annual or annual—basis. Finally, the cooperation among the different official agencies involved in collecting and compiling national and international accounts data could be improved by creating a national statistical committee composed of all parties involved and responsible for reconciling and validating all data before their publication.

17. To strengthen external debt management, the authorities launched, in 2002, a project to improve the database on external debt with financial and technical assistance from the World Bank and UNCTAD. The new debt management system, centralized within the Direction du Financement Extérieur (DFE) of the MOEF, became operational in mid-2003, following an inventory of external loans contracted or guaranteed by the government and appropriate training of staff. This system will progressively replace the old one (Excelworksheets) and a revised external debt database will be established covering the period from 1999 onward. Remaining issues to be dealt with are the completion of the inventory of all external loans, the reconciliation of debt service and disbursement data from DFE with those used in the budget, and the authorization of the DFE to co-sign all mandates related to external debt payments. 


\section{Djibouti: Core Statistical Indicators as of May 11, 2004}

\begin{tabular}{|c|c|c|c|c|c|c|c|c|c|c|c|c|c|}
\hline & $\begin{array}{c}\text { Exchange } \\
\text { Rates }\end{array}$ & $\begin{array}{c}\text { Interna- } \\
\text { tional } \\
\text { Reserves }\end{array}$ & $\begin{array}{l}\text { Reserve/ } \\
\text { Base } \\
\text { Money }\end{array}$ & $\begin{array}{c}\text { Central } \\
\text { Bank } \\
\text { Balance } \\
\text { Sheet }\end{array}$ & $\begin{array}{l}\text { Broad } \\
\text { Money }\end{array}$ & $\begin{array}{l}\text { Interest } \\
\text { Rates }\end{array}$ & $\begin{array}{c}\text { Consumer } \\
\text { Price } \\
\text { Index }\end{array}$ & $\begin{array}{l}\text { Exports/ } \\
\text { Imports }\end{array}$ & $\begin{array}{l}\text { Current } \\
\text { Account } \\
\text { Balance }\end{array}$ & \begin{tabular}{|c|} 
Overall \\
Governme \\
nt \\
Balance \\
\end{tabular} & $\begin{array}{l}\text { GDP/ } \\
\text { GNP }\end{array}$ & \multicolumn{2}{|c|}{$\begin{array}{l}\text { External Public } \\
\text { Debt }\end{array}$} \\
\hline $\begin{array}{l}\text { Date of latest } \\
\text { Observation }\end{array}$ & $\begin{array}{l}\text { April } \\
2004\end{array}$ & $\begin{array}{l}\text { March } \\
2004\end{array}$ & $\begin{array}{l}\text { March } \\
2004\end{array}$ & $\begin{array}{l}\text { March } \\
2004\end{array}$ & $\begin{array}{l}\text { March } \\
2004\end{array}$ & $\begin{array}{c}\text { Dec } \\
2003\end{array}$ & $\begin{array}{l}\text { March } \\
2003\end{array}$ & $\begin{array}{l}\text { March } \\
2002\end{array}$ & $\begin{array}{c}\text { Dec } \\
2002\end{array}$ & $\begin{array}{l}\text { March } \\
2004\end{array}$ & $\begin{array}{c}\text { Dec } \\
20021 /\end{array}$ & $\begin{array}{l}\text { March } \\
2003\end{array}$ & $\begin{array}{c}\text { March } \\
2003\end{array}$ \\
\hline Date Received & $\begin{array}{l}\text { May } \\
2004\end{array}$ & $\begin{array}{l}\text { April } \\
2004\end{array}$ & $\begin{array}{l}\text { April } \\
2004\end{array}$ & $\begin{array}{l}\text { April } \\
2004\end{array}$ & $\begin{array}{l}\text { April } \\
2004\end{array}$ & $\begin{array}{c}\text { Jan } \\
2004\end{array}$ & $\begin{array}{l}\text { April } \\
2004\end{array}$ & $\begin{array}{l}\text { Feb } \\
2003\end{array}$ & $\begin{array}{l}\text { Feb } \\
2003\end{array}$ & $\begin{array}{l}\text { April } \\
2004\end{array}$ & $\begin{array}{l}\text { Feb } \\
2003\end{array}$ & $\begin{array}{l}\text { April } \\
2004\end{array}$ & $\begin{array}{l}\text { April } \\
2004\end{array}$ \\
\hline $\begin{array}{l}\text { Frequency of } \\
\text { Data 2/ }\end{array}$ & M & M & M & M & M & M & M & Q & A & M & A & Q & A \\
\hline $\begin{array}{l}\text { Frequency of } \\
\text { Reporting }\end{array}$ & M & M & M & M & M & M & M & Q & A & M & A & Q & A \\
\hline Source of data & $\begin{array}{c}\text { Central } \\
\text { Bank }\end{array}$ & $\begin{array}{c}\text { Central } \\
\text { Bank }\end{array}$ & $\begin{array}{c}\text { Central } \\
\text { Bank }\end{array}$ & $\begin{array}{c}\text { Central } \\
\text { Bank }\end{array}$ & $\begin{array}{c}\text { Central } \\
\text { Bank }\end{array}$ & $\begin{array}{l}\text { Central } \\
\text { Bank }\end{array}$ & $\begin{array}{l}\text { DISED/ } \\
\text { Ministry } \\
\text { of } \\
\text { Finance }\end{array}$ & $\begin{array}{c}\text { DISED/ } \\
\text { Central } \\
\text { Bank }\end{array}$ & $\begin{array}{c}\text { DISED/ } \\
\text { Central } \\
\text { Bank }\end{array}$ & $\begin{array}{l}\text { Ministry } \\
\text { of } \\
\text { Finance }\end{array}$ & $\begin{array}{l}\text { DISED/ } \\
\text { Ministry } \\
\text { of } \\
\text { Finance }\end{array}$ & $\begin{array}{c}\text { DFE/ } \\
\text { Ministry } \\
\text { of } \\
\text { Finance }\end{array}$ & $\begin{array}{c}\text { DFE/ } \\
\text { Ministry } \\
\text { of } \\
\text { Finance }\end{array}$ \\
\hline $\begin{array}{l}\text { Mode of } \\
\text { reporting }\end{array}$ & $\begin{array}{c}\text { Fax/ } \\
\text { Cable to } \\
\text { IMF }\end{array}$ & $\begin{array}{c}\text { Fax/ } \\
\text { Cable to } \\
\text { IMF }\end{array}$ & $\begin{array}{c}\text { Fax/ } \\
\text { Cable to } \\
\text { IMF/ } \\
\text { E-mail }\end{array}$ & $\begin{array}{c}\text { Fax/ } \\
\text { Cable to } \\
\text { IMF/ } \\
\text { E-mail }\end{array}$ & $\begin{array}{c}\text { Fax/ } \\
\text { Cable to } \\
\text { IMF/ } \\
\text { E-mail }\end{array}$ & $\begin{array}{c}\text { Fax/ } \\
\text { Cable to } \\
\text { IMF or } \\
\text { Mission/ } \\
\text { E-mail }\end{array}$ & $\begin{array}{c}\text { Fax } \\
\text { Cable to } \\
\text { IMF or } \\
\text { Mission }\end{array}$ & $\begin{array}{c}\text { Fax } \\
\text { Cable to } \\
\text { IMF or } \\
\text { Mission }\end{array}$ & $\begin{array}{c}\text { Fax } \\
\text { Cable to } \\
\text { IMF or } \\
\text { Mission }\end{array}$ & $\begin{array}{c}\text { Fax } \\
\text { Cable to } \\
\text { IMF or } \\
\text { Mission }\end{array}$ & $\begin{array}{c}\text { Fax } \\
\text { Cable to } \\
\text { IMF or } \\
\text { Mission }\end{array}$ & Mission & Mission \\
\hline Confidentiality $3 /$ & $\mathrm{C}$ & $\mathrm{C}$ & $\mathrm{C}$ & $\mathrm{C}$ & $\mathrm{C}$ & $\mathrm{C}$ & $\mathrm{C}$ & $\mathrm{C}$ & $\mathrm{C}$ & $\mathrm{C}$ & $\mathrm{C}$ & $\mathrm{C}$ & $\mathrm{C}$ \\
\hline
\end{tabular}

1/ GDP data is entirely estimated by the staff on the basis of partial data, provided by the authorities.

2/ D = Daily; $\mathrm{W}=$ Weekly; $\mathrm{M}=$ Monthly; $\mathrm{Q}=$ quarterly; $\mathrm{A}=$ Annual.

$3 / \mathrm{C}=$ Unrestricted. 
Djibouti, February 29, 2004

\author{
Mr. Horst Köhler \\ Managing Director \\ International Monetary Fund \\ Washington, D.C. 20431
}

Dear Mr. Köhler:

18. The economy and the social situation in Djibouti are still weak, despite seven years of adjustment effort under the IMF-supported programs. The fiscal position has gradually been restored and progress has been made toward reforming public finances. The heavy domestic fiscal arrears have started to come down since 2001. However, the structural reform program, intended to remove the obstacles to growth, has not been completed. Economic growth has consequently remained insufficient to foster job creation and reduce poverty.

19. Last year, the government expressed interest in negotiating a second arrangement under the Poverty Reduction and Growth Facility (PRGF). However, the staff considered that because of substantial additional budgetary resources from military agreements with France and the United States, the Republic of Djibouti would not, for the time being, need a Fund program with drawings. Moreover, during its recent 2003 Article IV discussions, the Executive Board of the IMF expressed the wish that the authorities establish a strong track record of implementing their economic and financial policy, before concluding such an agreement. In particular, it wished for completion of the last program's structural reforms agenda to enhance growth, and for the adoption of a 2004 budget that would support growth and poverty reduction.

20. The attached Memorandum on Economic and Financial Policies (MEFP) describes the structural reform and macroeconomic adjustment program for 2004. The government believes that the policies described in the attached MEFP clearly reflect the authorities' commitment to economic reforms and lay a solid foundation for implementing their economic policy. These policies are also a good starting point for subsequently embarking on the negotiation of a second PRGF arrangement with the IMF. The government therefore requests that the Fund staff closely monitor execution of this program (as is usually done under Fund-supported programs) covering the period January-December 2004.

21. The government will provide Fund staff with all necessary information to assess policy implementation and fulfillment of the program targets. The authorities also intend to review with Fund staff the progress made under the program every three months. 
22. The government appreciates the help that the IMF has provided in preparing the economic reform programs since 1996, and attaches considerable importance to continued collaboration with the IMF.

Accept, Sir, the assurance of our high consideration.

/s/

Yacin Elmi Bouh

Minister of Economy, Finance, and Planning, in charge of Privatization
$/ \mathrm{s} /$

Djama M. Haïd

Governor

Central Bank of Djibouti 


\section{MEMORANDUM ON ECONOMIC AND FINANCIAL POLICIES}

\section{INTRODUCTION}

1. Over the past 15 years, Djibouti's economy has experienced severe domestic and external shocks, including a civil war during which the size of the armed forces jumped from 4,000 to 16,000 in a single year. In addition, our country has had to cope with flows of refugees from neighboring countries estimated at 120,000 in 1999 (i.e., approximately 20 percent of the population), lingering regional conflicts, and a reduction in French military presence.

2. Faced with this difficult situation, adjustment has become an unavoidable economic necessity for our country to return to a sound macroeconomic environment. This was the option chosen by the government in April 1996 when a stand-by program (1996-99) was put in place, followed by a Poverty Reduction and Growth Facility (PRGF) arrangement, from October 1999 to December 2002. During the six years of fiscal adjustment, the authorities have made considerable efforts to rehabilitate the macroeconomic framework.

3. After three years of implementation (1999-2002), this program has made it possible to: (a) stabilize tax revenues by enhancing the efficiency of revenue collection efforts through the adoption of a package of legislative and practical measures; (b) rationalize expenditure through implementation of a cash-flow management plan; (c) raise the expenditures allocated to the social sectors; and (d) stabilize the wage bill/budgetary revenue ratio.

4. However, while the goals of macroeconomic stabilization have been achieved, strong and sustainable economic growth has not yet been restored. The adverse effects of the adjustment measures have weighed most heavily upon the most vulnerable strata of Djibouti's population; this is illustrated by the results of the most recent household survey conducted in July 2002 (EDAM-2), indicating that 45.2 percent of the population is poor.

5. Poverty reduction in Djibouti must thus be the cornerstone of any efforts to promote development in our country. The Poverty Reduction Strategy Paper (PRSP) prepared by the government, using a participatory approach, is a response to this challenge. Our main goal is to build an enabling environment for growth and the accumulation of human capital in such a way as to achieve long-term reductions in poverty and unemployment while improving the living conditions of all our citizens. Such a strategy reflects a long-term vision aimed at harnessing Djibouti's strategic assets, its geographic location, and its port, and at developing its human resources, so as to achieve far-reaching improvements in the economy's competitiveness and to acquire an advantageous position in the world economy.

6. Against this backdrop, the government attaches the utmost importance to continuing its partnership with the IMF on the basis of a new program. The measures proposed in this 
memorandum reflect a political commitment to pursuing the reforms, having due regard for the importance of mobilizing additional external resources associated with the government's poverty reduction strategy.

\section{NATiOnAl ECONOMiC DEVELOPMENTS IN 2003}

7. Economic activity in 2003 presented encouraging results. The transportation systemthe linchpin of the country's economic activity — made significant headway in comparison with the same period in 2002:

- Port traffic experienced a sharp increase overall, in the amount of 40 percent (46 percent for imports, 21 percent for exports); and

- Air transportation (commercial and noncommercial) made major strides with a 96 percent increase in aircraft movements.

8. Economic growth was also bolstered by electricity production, which grew by 5.2 percent between 2002 and 2003. Furthermore, public investment (including spending on additional social programs) through December 31, 2003 (DF 7.436 billion) was up by 58.4 percent compared to the same period in 2002. These investments focused on infrastructure and roads (32 percent), urban development and housing (35 percent), national education (13 percent), and government participation in two new enterprises.

9. Accordingly, based on the results outlined above, the growth in real GDP is estimated at 3.5 percent by end-2003. This level of growth will help improve the rate of growth in per capita GDP, which should turn positive for the first time in a decade ( +0.7 percent), in spite of galloping population growth estimated at 2.8 percent, and inflation (largely imported) at 2.1 percent (up from 1.5 percent in 2002).

10. On the monetary side, at end-December 2003, M3 had grown by 17.8 percent over the same period in 2002. This increase chiefly reflects the accumulation of local currency deposits. Conversely, net foreign assets grew by 26.8 percent, particularly those of commercial banks (DF 46.172 billion), while credit to the economy (DF 26.226 billion) recorded a drop of -2.9 percent.

11. The government budget outturn as of December 31, 2003 reflects total revenues of DF 37.962 billion (up by 22.7 percent as a result of the additional revenues collected from foreign military forces and from domestic resources, which rose by 4.3 percent), and total expenditures in the amount of DF 40.490 billion-i.e., an upturn of 16.8 percent largely reflecting increases in public investment expenditure $(+58.4$ percent) and current expenditure $(+10.3$ percent). The largest element in this expenditure was the wage bill, which nonetheless remained stable in terms of the GDP and the slight increase was due in part to the inclusion in the budget of the costs involved in incorporating the FRUD fighters in the army in 2003, 
as a result of the peace accord signed in 1999 and 2001 with the FRUD and the FRUD army. This situation gave rise to an overall deficit on a payment order basis of DF 2.528 billioni.e., 2.3 percent of GDP (compared to a deficit of 3.5 percent of GDP in 2002).

12. Thanks to additional revenues, arrears were settled more rapidly in 2003. Pension funds and civil servants were the principal beneficiaries. In addition, the Djibouti government has refrained from accumulating external arrears.

\section{MEdIUM-TERM MACROECONOMIC FrAMEWORK AND STRATEGY (2004-06)}

13. The reform program focuses on putting in place a favorable macroeconomic and structural environment with the following objectives:

- The establishment of a viable macroeconomic framework. The policy pursued by the government is especially designed to control the budget deficit while allocating public expenditure to poverty reduction programs.

- $\quad$ Private sector-led growth with the development of an environment conducive to investment. The chosen strategy focuses on four main themes: (a) putting in place a legal framework favorable to private investment; (b) improving the labor environment; (c) pursuing reforms to lower factor costs and to improve the management of public enterprises; and (d) strengthening good governance.

14. In this context, the macroeconomic objectives for the period 2004-06 are as follows:

- Achieve an average real GDP growth rate of 4.6 percent. Investment is vital to the growth strategy, and public investment is expected to grow from a budgeted level of 5.9 percent of GDP in 2004 to 16.3 percent of GDP in 2006 (including financing to be secured);

- Contain inflation, as measured by the CPI, to 2 percent;

- $\quad$ Place fiscal management and supervision on sound foundations, through continued efforts to modernize taxation and strengthen government expenditure management; and

- Maintain the debt service/GDP ratio at 1.05 percent.

15. However, higher growth rates can only be achieved if the private sector responds favorably to the reforms. These key structural reforms will focus on the following main areas:

- In the tax reform area, the objective is to improve revenue collection and thereby ease the tax burden without adversely affecting the overall fiscal position; 
- For government expenditure, the objective is to improve management by enhancing the performance of productive public and social services (education, including training; and health, including prevention and sanitation);

- For structural reforms, the objective is to improve external competitiveness and strengthen good governance, particularly by restoring the external competitiveness of the economy through the adoption of reforms of the labor, commerce, and investment codes and the establishment of an operational "onestop shop"; and

- $\quad$ The banking system will be improved through strengthened supervision.

- Aware of the fact that building an environment conducive to private investment will require lowering factor costs, the government will build, in 2004, upon the progress in the reforms of public enterprises (Electricité de Djibouti, l'Office Nationale des Eaux de Djibouti, and Djib-Télécom), while enhancing their financial viability. The completion of these reforms will require financial assistance from donors, and, in particular, the World Bank. To achieve these objectives, the government will set up a body in the ministry in charge of privatization to monitor implementation of their terms and conditions.

\section{The Program for 2004}

\section{A. Macroeconomic Coordination}

16. The policies in 2004 and beyond will focus on: (a) achieving sustainable increases in the growth rate; and (b) strengthening economic competitiveness. The government must address these two issues head-on if it is to ensure the successful implementation of the national poverty reduction strategy.

17. The macroeconomic goals envisaged for 2004 are to:

- $\quad$ Raise the rate of real GDP growth to 4.1 percent, which should make it possible to achieve a real per capita GDP growth of +1.3 percent, given a population growth rate estimated at 2.8 percent per year;

- Contain the inflation rate to a level not exceeding 2 percent; and

- Pursue fiscal consolidation through improvements in tax revenues coupled with intensified collection efforts, and expenditure control, enhancing their efficiency and reallocating them to priority sectors, in addition to the gradual settlement of the government's domestic debt. 
16. Economic growth in 2004 will be supported by the gradual emergence of a new and dynamic environment in the services sector, thanks to the planned construction of the Doraleh port complex (Oil Terminal, Container Terminal, and the industrial and commercial free zone). The Doraleh project, which began in June 2003, will in the near term create 500 new jobs as work progresses.

17. Public investment in the transport and telecommunications sectors (new road for the Djibouti-Galafi corridor, construction of urban bypass roads for the RN1 highway, and installation of a fiber-optic telecommunications network) coupled with further construction of low-cost housing and school and public health infrastructure, as well as productive investment in fisheries, agriculture (Special Food Security project (PSSA) and rural welldrilling), and livestock (future center for the re-exportation of cattle) will help boost the growth rate in 2004 .

18. The main economic policy measures envisaged in the program are highlighted below.

\section{B. Fiscal Policy}

19. The budget for FY 2004, adopted by Parliament on December 29, 2003 and promulgated by the President of the Republic, looks as follows compared to estimates results for 2003: total revenues up by 1.29 percent, despite the 12.3 percent reduction in additional resources from France and the United States. Own domestic resources are up by 4.3 percent. Government expenditure is down by 0.93 percent from 2003 with a slight increase of 0.29 percent in current expenditure, and a 6.37 percent decline in investment expenditure.

20. With respect to revenues, the measures planned for meeting the 2004 budget goals are as follows:

- To address the revenue shortfall resulting from the reform of the business license tax, tax supervision will be strengthened by revitalizing the general audit office through providing the units in charge of supervising taxpayers with enough physical and human resources to conduct supervision of the large enterprises;

- To improve the property tax collection rate, the government will continue to publish the list of defaulting taxpayers in the official journal and will confiscate movable and fixed assets;

- To address a possible decline in revenues from the domestic consumption tax (following a reduction in the tax rates on some products), the tax administration will step up its efforts to audit imported goods;

- In August 2004, to unify and simplify the tax exemptions system the government will merge the various preferential tax regimes and include exemptions in the general tax code; and 
- The government will strengthen border inspections to combat smuggling and increase the collection of the surtax on alcohol and cigarettes.

In addition, the computerization of the tax administration, which will be completed by December 2004, will facilitate efforts to administer taxes more efficiently.

21. As for personnel expenditure, the government undertakes to:

- Ensure the operational implementation of the single registry for civil servants by September 2004 by integrating both the separate civil service and finance programs;

- Continue the demobilization of personnel from the army and the security forces (500 in the first half of 2004);

- Retire 68 civil servants and 140 government-affiliated persons (conventionnés);

- Continue the staffing freeze in the civil service, except for education, health, and the judiciary; and

- $\quad$ Limit the gross impact on the budget in 2004 of the recruitment of new staff in education, health, and the judiciary to DF 550 million.

22. Spending on goods and services has increased significantly in recent years as a result of higher expenditure on power, water, and telephone services. The government is committed to:

- $\quad$ Lowering these expenditures by further educating the technical ministries and controlling the billing process more effectively; and

- Making the Radio and Television of Djibouti (RTD), the Palais du Peuple, and the Hassan Gouled Stadium, whose water and electricity bills are paid by the government, participate in efforts to reduce utility outlays.

25. To improve the management of government expenditure and of the institutions responsible for preparing and monitoring the budget, the government intends to:

- Limit pre-payment order expenditures to such outlays as are stipulated by law and settle such expenses quarterly, such as the Office of the President of the Republic, embassies, etc.;

- Continue the strict enforcement of the cash-flow management plan and limit check-exchanging arrangements to the following public enterprises: EDD and ONED; 
- Make fully effective the reorganization of the ministry of finance to strengthen the budget preparation and execution process;

- Restrain the growth in expenditures on goods, services, and transfers unrelated to poverty;

- Establish an adequate framework for monitoring the implementation of the public investment program underpinning the PRSP and the progress made in redirecting expenditure toward the poor. Thus, in view of the uncertainties surrounding a portion of the fiscal revenues, such as grants, public expenditure programming will be undertaken in a medium-term framework, with publication of semiannual reports on priority social spending developments;

- Start preparations for implementing a social safety net for the most vulnerable members of society with assistance from the World Bank;

- Include in the budget all types of external financing (grants and loans), including all assistance in the form of military aid; and

- Avoid all kinds of extrabudgetary expenditure (including military expenditure).

\section{Financial Sector Reform}

23. In the area of financial sector reforms, the authorities have continued their efforts to ensure the integrity and efficiency of the banking and financial system. For that purpose, the authorities adopted a new anti-money laundering law at end-2002 and have proposed amendments to the Central Bank of Djibouti (BCD) Charter and the banking law. The revised texts are to be submitted to the Council of Ministers for approval and are expected to be adopted by Parliament by end-June 2004 .

24. With regard to the financial system supervision program, in December 2003, the BCD undertook an on-site inspection of a commercial bank with technical assistance from an IMF advisor. The $\mathrm{BCD}$ also carried out on-site inspections of three exchange bureaus during the second half of 2003. The BCD will inspect the main exchange bureaus in 2004, and will continue to strengthen its capacity to oversee the banking system with on-site audits of at least one bank per year.

25. As in the three preceding years, the external audit for the BCD's 2002 accounts was performed by an international audit firm at end-2003. The BCD will continue to have its accounts audited by external auditors in 2004, and will publish its financial statements together with the auditors' opinion.

26. Regarding the liquidation of two banks (BDMO and Albaraka), the efforts to recover their claims and the gradual repayment of depositors continued in 2003. However, 
the authorities intend to wrap up the liquidation process before end-2004, notwithstanding the slow pace of legal proceedings and the risks arising from certain debtors' insolvency.

27. The authorities intend to put in place an appropriate regulatory framework for microfinance and to subject those institutions engaged in this activity to regular supervision by the BCD.

28. To give depositors access to a broader range of financial products, the authorities have been considering developing new financial products in Djibouti.

29. Finally, in the area of technical assistance, in 2004, the authorities intend to enlist the services of the IMF to support BCD staff in regard to new financial products (financial leasing, young entrepreneur loans, risk capital, and financial engineering), monetary statistics, and anti-money laundering, by strengthening financial investigation techniques as part of the continuous training program for supervisors.

\section{External Sector Policy}

30. Debt management and monitoring are one of the government's priorities.

After establishing in 2001 an agency with sole responsibility for the State's external resources, the Djibouti authorities acquired and installed a debt-management and analysis system in 2003. The establishment of this database enabled an exhaustive classification of loan agreements, recording the terms of those loans, as well as past and present drawings and payments.

31. In 2004, the government will pursue its cautious debt management policy, and will refrain from contracting or backing nonconcessional loans. Furthermore, the government will include, in the external debt service, those outlays related to new external loans, while refraining from accumulating new external and domestic payments arrears. The government will respect the order of priority between the various creditors in the plan for settling domestic payments arrears (private creditors, salaried government employees, social public entities, and public enterprises). Furthermore, effective July 2004, the government will resume contact with Paris Club creditors, particularly with Spain and Italy, in order to restart negotiations.

\section{E. Structural Reforms: Improving Competitiveness and Poverty Reduction}

32. The government attaches the utmost importance to the promotion of private investment, which is the driving force behind economic growth. In order to achieve this objective, it is planned to adopt a new investment code designed to attract foreign capital in 2004. This code will enable the exemptions system to be simplified and rationalized. 
33. Also, to enhance labor market flexibility, the government will adopt by June 2004 the draft labor code prepared by the committee established for this purpose by the ministry of labor and national solidarity, which has had the benefit of input from the International Labor Office (ILO).

34. The authorities intend to promote the expansion of private enterprise by implementing a strategy and mechanisms supported by small- and medium-scale enterprises. The purpose of the approved management centers will be to facilitate and to promote small- and mediumscale enterprises' competitiveness. The authorities will also promote the expansion of microfinance in particular by preparing a national microfinance strategy.

35. The authorities will encourage private sector initiatives by putting in place a plan to restructure the power and water sectors.

36. To promote good governance, the government intends to strengthen the management of public expenditure and to enhance its efficiency. The general aim will be to build upon results already achieved in accordance with the following criteria:

- Effective implementation of the new measures to improve budget preparation and control and monitoring of expenditure; and

- Enhanced control of government finances through publication of the 2002 Report of the Chamber of Accounts and Fiscal Discipline.

\section{F. Statistical System}

37. To be able to have a statistical system that meets international standards in terms of quality, frequency, and dissemination, the government has decided to participate in the IMF's General Data Dissemination System (GDDS). The government will actively seek to implement the IMF technical assistance missions' recommendations in the fiscal and national accounts areas.

\section{Program Monitoring}

38. Program performance will be monitored through quarterly indicative targets, structural benchmarks, and quarterly progress assessments by IMF staff. The indicative targets for end-March, end-June, end-September, and end-December 2004, as described in Table 1, will focus on: (a) a ceiling on the wage bill; (b) a floor on fiscal revenues (tax and non-tax); (c) a ceiling on spending on goods and services and transfers (excluding foreignfinanced military expenditure); (d) a ceiling on net outstanding domestic arrears; (e) a ceiling on net central bank credit to the government; and (f) a floor on net international reserves. The program also includes a zero ceiling on: new external arrears; nonconcessional external debt (except for commercial credit) contracted or backed by the government or a public 
enterprise; and government borrowings from public enterprises or commercial banks. The principal economic policy measures contemplated by the program are listed in Annex I, including those that are structural benchmarks.

39. The approval by IMF management of the letter of intent and the memorandum on economic and financial policies and their submission to the Executive Board are subject to execution of the following prior measures: (a) completion of the demobilization of 250 former combatants; (b) accounting for the use of the US $\$ 4.75$ million disbursed by the United States in October 2002; (c) retirement of the entitled government employees; and (d) publication of the 2002 Report of the Chamber of Accounts and Fiscal Discipline. Djibouti will regularly consult the IMF, in accordance with the IMF's policies on the matter, about progress in implementing the policies and measures prescribed in the staff-monitored program. 
Table 1. Djibouti: Indicative Targets, 20041/

(In millions of Djibouti francs, unless otherwise stated)

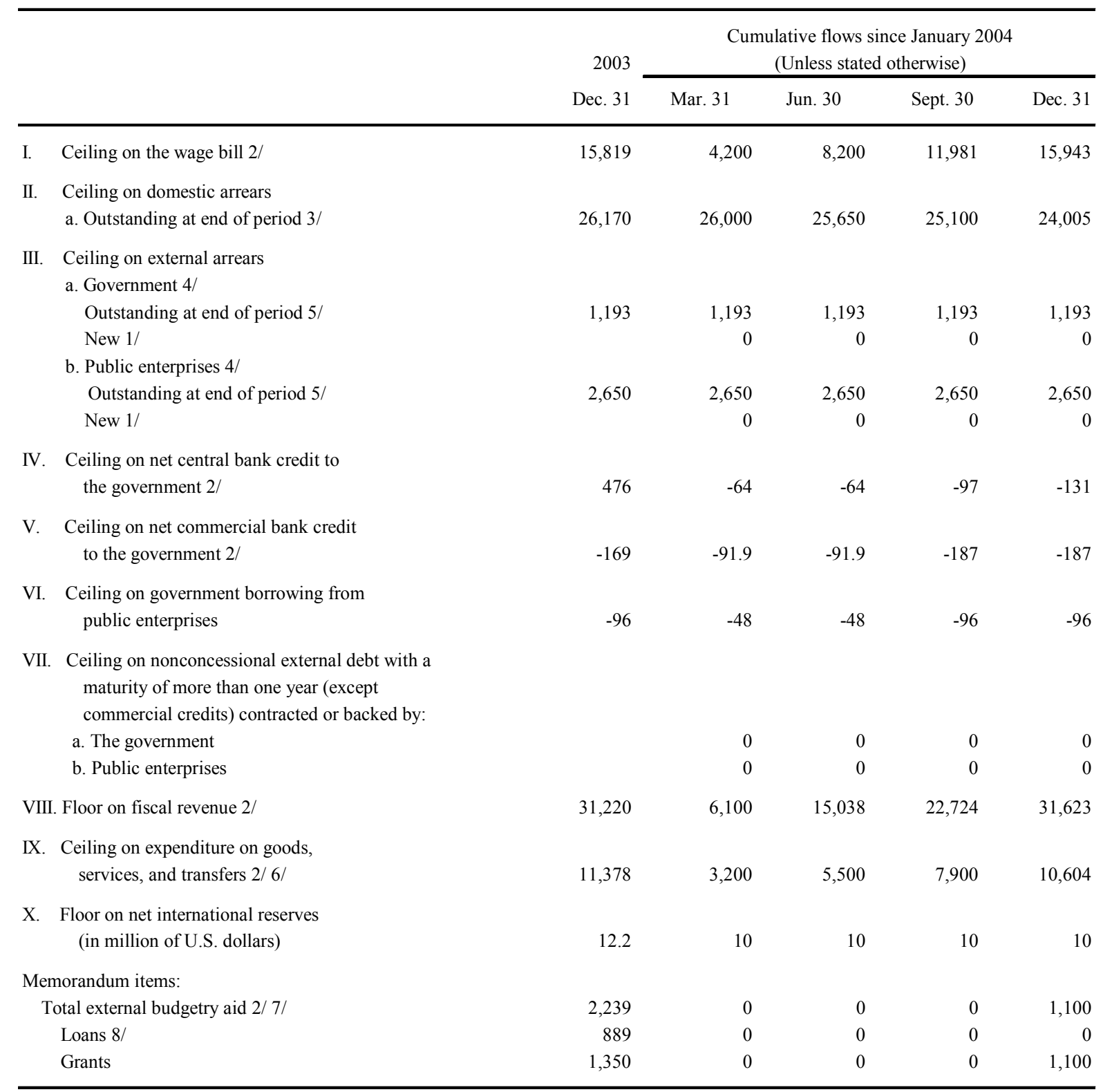

1/ See Annex IV, technical memorandum of understanding, for a definition of indicative targets.

2/ Cumulative flows from beginning of the year.

3 / If the net external budgetary financing flows are lower (higher) than the programmed amounts, the targets set for arrears repayment will be adjusted downward (upward) by the amount of the shortfall (excess).

4/ The ceilings or targets will be lowered by the amount that might be obtained through debt rescheduling or cancellation.

5/ All subsequent upward (downward) revisions of this amount due to improvement in the data will cause an upward (downward) adjustment of the ceilings and targets in each subsequent period.

6/ Includes transfers related to peace agreements.

7/ External loans and grants concerned are solely those that are fungible and exclude all loans and grants under the investment program.

8/ Except IMF and AMF. 
Table 2. Djibouti: Prior Actions, Indicative Targets, and Structural Benchmarks for the 2004 Program

I. Prior actions for the approval by Fund management of the letter of intent and memorandum on economic and financial policies

- $\quad$ Completion of the demobilization of 250 ex-combatants.

- $\quad$ Accounting for the use of the $\$ 4.75$ million disbursed by the United States in October 2002.

- $\quad$ Retirement of government employees entitled to retire (done).

- $\quad$ Publication of the 2002 Report of the Chamber of Accounts and Fiscal Discipline.

\section{Indicative Targets}

- $\quad$ See Table 1, Annex I.

III. Structural Benchmarks

\section{End-March 2004}

- $\quad$ Make fully effective the reorganization, adopted end-2002, of the ministry of finance (adoption of the implementing decree).

\section{End-June 2004}

- $\quad$ Complete the demobilization of 250 former combatants.

- $\quad$ Finalize the projected unification and simplification of the tax exemption regime by merging the various preferential tax regimes and by including remaining exemptions in the general tax code.

- Have the National Assembly adopt the revisions to the banking legislation and the central bank charter.

- $\quad$ Enforce the decree revising the banking legislation.

- $\quad$ Adopt the new labor code.

- $\quad$ Adopt a new investment code and revise the legislation on free zones. 
- $\quad$ Publish a detailed report on priority social expenditure during the first six months of 2004.

\section{End-September 2004}

- $\quad$ Adopt the projected unification and simplification of the tax exemption regime by incorporating it into the revised finance law.

- With World Bank assistance, draw up a plan to restructure the power and water sectors.

- Implement the unified registry of civil servants.

\section{End-December 2004}

- $\quad$ Complete the computerization of the tax administration

- $\quad$ Draft and adopt a commercial code.

- $\quad$ Publish a detailed report on priority social spending during the last six months of 2004.

- $\quad$ Put in place an appropriate regulatory framework for microfinance and subject institutions engaged in this activity to regular supervision by the central bank.

\section{Continuous Structural Benchmarks}

- $\quad$ Rigorously enforce the monthly cash-flow management plan.

- $\quad$ Limit pre-payment order expenditure to such outlays stipulated by law.

- $\quad$ The government will report to the Fund each quarter, with a lag of four weeks, its data on foreign trade and foreign debt, and each month, with a lag of four weeks, its data on revenues, expenditures, and domestic and external arrears. 
Table 3. Djibouti: Policy Matrix Under the 2004 Staff-Monitored Program

\begin{tabular}{|c|c|c|}
\hline Areas & Objectives & Strategy and Measures \\
\hline $\begin{array}{l}\text { Government } \\
\text { Finances }\end{array}$ & $\begin{array}{l}\text { Put in place a viable } \\
\text { macroeconomic framework } \\
\text { - Continue the reform of fiscal } \\
\text { management } \\
\text { - Continue to rehabilitate } \\
\text { government finances by stepping } \\
\text { up collections and by improving } \\
\text { expenditure control while, at the } \\
\text { same time, improving their } \\
\text { efficiency and redirecting } \\
\text { expenditure toward priority } \\
\text { sectors }\end{array}$ & $\begin{array}{l}\text { - Start preparatory work on the adoption of the VAT } \\
\text { by 2006; } \\
\text { - Unify and simplify the tax exemptions regime by } \\
\text { merging the various preferential tax regimes and } \\
\text { incorporate all remaining exemptions in the general } \\
\text { tax code (structural benchmark); } \\
\text { - Improve tax collection by revitalizing the general audit } \\
\text { office and by reinforcing oversight of the collection of } \\
\text { consumer taxes on imports; } \\
\text { - Complete the computerization of tax administration } \\
\text { (structural benchmark); } \\
\text { - Implement the unified registry of civil servants } \\
\text { (structural benchmark); } \\
\text { - Maintain the hiring freeze, except in education, health, } \\
\text { and the judiciary; } \\
\text { - Increase the proportion of priority social spending in } \\
\text { the budget; } \\
\text { - Restrain non-poverty-related expenditure growth of } \\
\text { goods, services, and transfers; } \\
\text { - Make the Radio and Television of Djibouti, the Palais } \\
\text { du Peuple, and the Hassan Gouled Stadium, whose } \\
\text { water and electricity bills are paid by the government, } \\
\text { join in the effort to cut utility outlays; } \\
\text { of finance, adopted end-2002, (passage of the } \\
\text { - Reduce the wage bill through the demobilization } \\
\text { program and by retiring those government employees } \\
\text { who are entitled to retire (structural benchmark); } \\
\text { - Rigorously enforce the monthly cash-flow } \\
\text { management plan (permanent structural benchmark); } \\
\text { - Limit pre-payment order expenditure to such outlays } \\
\text { for the most vulnerable members of society, with } \\
\text { assistance from the World Bank; } \\
\text { - lated by law (permanent structural benchmark); } \\
\text { - }\end{array}$ \\
\hline
\end{tabular}


Table 3. Djibouti: Policy Matrix Under the 2004 Staff-Monitored Program

\begin{tabular}{|c|c|c|}
\hline Areas & Objectives & Strategy and Measures \\
\hline & & $\begin{array}{l}\text { implementing decree) (structural benchmark); } \\
\text { - Establish an appropriate framework for monitoring } \\
\text { execution of the public investment program; and } \\
\text { - Given the uncertainty surrounding part of fiscal } \\
\text { revenues, such as grants, programming government } \\
\text { expenditure should be undertaken in a medium-term } \\
\text { perspective. }\end{array}$ \\
\hline Financial Sector & $\begin{array}{l}\text { - Preserve the integrity of the } \\
\text { currency board arrangement } \\
\text { - Consolidate the banking system }\end{array}$ & $\begin{array}{l}\text { - Continue reinforcing surveillance and controls over } \\
\text { banks and exchange bureaus; } \\
\text { - Complete the audit of a commercial bank and of the } \\
\text { main exchange bureaus; } \\
\text { - Have the National Assembly adopt the revisions to the } \\
\text { banking legislation and the Central Bank Charter, and } \\
\text { incorporate the supervision of financial institutions } \\
\text { (structural benchmark); } \\
\text { - Enforce the decree revising banking } \\
\text { legislation (structural benchmark); } \\
\text { - Put in place an appropriate regulatory framework for } \\
\text { microfinance and subject institutions engaged in this } \\
\text { activity to regular supervision by the central bank } \\
\text { (structural benchmark); } \\
\text { - Complete the liquidation of the two commercial } \\
\text { banks; and } \\
\text { - Continue to have the central bank's accounts audited } \\
\text { by internationally recognized external auditors. }\end{array}$ \\
\hline $\begin{array}{l}\text { Official Debt and } \\
\text { Domestic and } \\
\text { Foreign Arrears }\end{array}$ & $\begin{array}{l}\text { - Continue prudent debt } \\
\text { management }\end{array}$ & $\begin{array}{l}\text { - Refrain the government from contracting or } \\
\text { guaranteeing nonconcessional loans; } \\
\text { - Not accumulate new external payments arrears; } \\
\text { - Resume contact with Paris Club members; } \\
\text { - Progressively reduce the stock of domestic payments } \\
\text { arrears; and } \\
\text { - Respect the order of priority between the various } \\
\text { creditors in the plan for settling domestic payments } \\
\text { arrears (private creditors, salaried government }\end{array}$ \\
\hline
\end{tabular}


Table 3. Djibouti: Policy Matrix Under the 2004 Staff-Monitored Program

\begin{tabular}{|c|c|c|}
\hline Areas & Objectives & Strategy and Measures \\
\hline & & $\begin{array}{l}\text { employees, social public entities, and public } \\
\text { enterprises), approved by presidential decree in } \\
\text { September } 2003 \text {. }\end{array}$ \\
\hline $\begin{array}{l}\text { Structural } \\
\text { Reforms }\end{array}$ & $\begin{array}{l}\text { - Strengthen competitiveness by } \\
\text { lowering the costs of the factors } \\
\text { of production } \\
\text { - Foster a favorable legal } \\
\text { environment for foreign } \\
\text { investment } \\
\text { - Improve the operation of the } \\
\text { labor market }\end{array}$ & $\begin{array}{l}\text { - Build upon progress in reforming the public } \\
\text { enterprises (EDD, ONED) and improve their financial } \\
\text { profitability; } \\
\text { - Draw up a plan to restructure the power and water } \\
\text { sector, with World Bank assistance (structural } \\
\text { benchmark); } \\
\text { - Draft and adopt a commercial code; } \\
\text { - Adopt a new investment code and revise legislation on } \\
\text { free zones (structural benchmark); and } \\
\text { - Adopt the new labor code (structural benchmark). }\end{array}$ \\
\hline $\begin{array}{l}\text { Governance and } \\
\text { Transparency }\end{array}$ & $\begin{array}{l}\text { - Strengthen good governance } \\
\text { - Improve transparency }\end{array}$ & $\begin{array}{l}\text { - Avoid all extrabudgetary expenditure; } \\
\text { - Include in the budget all types of external financing, } \\
\text { including all military related receipts; } \\
\text { - Publish the } 2002 \text { Report of the Chamber of Accounts } \\
\text { and Fiscal Discipline; and } \\
\text { - Publish semiannual reports on priority social spending } \\
\text { as detailed as possible. }\end{array}$ \\
\hline
\end{tabular}




\section{DJIBOUTI-TECHNICAL MEMORANDUM OF UNDERSTANDING}

This Technical Memorandum of Understanding (TMU) contains further information regarding: (a) the indicative targets detailed in the table and Annexes to the Memorandum on Economic and Financial Policies (MEFP); (b) basic information to be conveyed to the Fund through its resident mission; and (c) the authorities' plan for monitoring program execution.

\section{INDICATIVE TARGETS}

The definition of aggregates on which ceilings are imposed are given below:

- Domestic fiscal revenue includes all receipts from direct and indirect taxes, other taxes, and nontax revenues, as well as all other receipts from foreign military forces located in Djibouti.

The wage bill includes, in particular, all wages, salaries, fees, compensation, remuneration, benefits, and allowances that the government pays to civilian, military, or security personnel that it employs (permanently or temporarily), as well as all other general government employees, regardless of the method of payment (cash, check, transfer, or any other type of payment) or the type of agency making such payments (treasury or any other agency acting on behalf of the government). The ceilings and targets include savings linked to projected retirements and net savings arising from the demobilization program for security and military personnel.

- Expenditure on goods and services and transfers include all operating costs (apart from payroll and maintenance costs) of the central government and municipalities (including energy costs), as well as government subsidies to private, public, or autonomous agencies. Transfers operations also include scholarships, grants, contributions to paying rent, subsistence, annuities, contributions to government agencies as well as consolidating peace agreements and the youth training program. Foreign-financed military spending is excluded.

- $\quad$ Social expenditure includes all spending on poverty reduction by providing access to training, on health care, on improving the legal system, for greater equity among citizens, as well as improving the standard of living, including, among other things, access to drinking water and treatment of sewage.

- Domestic arrears include, among other things, payroll arrears, payments to private suppliers, and payments into retirement funds.

- Net central bank credit to the government is defined as all claims that the central bank holds on government agencies less government agencies' deposits in the central bank. These deposits include, inter alia: the reserve fund, treasury cash holdings, and miscellaneous deposits. Miscellaneous deposits consist mainly of: deposits to blocked 
accounts, deposits for payment of exceptional grants, current accounts, deposits to special accounts, and counterpart funds for loans and grants by way of external budgetary support. These deposits do not include counterpart funds arising from foreign loans and grants that are not intended for budgetary support.

Net bank credit to the government consists of all commercial bank claims on the government (including overdrafts, and bonds and securities issued by government agencies, held by commercial banks), less all deposits by government agencies to these banks. These deposits consist mainly of: deposits to blocked accounts, deposits for payment of exceptional grants, current accounts, deposits to special accounts, and counterpart funds for loans and grants by way of external budgetary support. These deposits do not include counterpart funds arising from foreign loans and grants that are not intended for budgetary support. The commercial banks consist of the three presently operating banks in Djibouti.

- Borrowings from public enterprises are defined as the total amount received by the government constituting debt to such enterprises. They include, inter alia certificates of deposit, loans and advances, and deposits to the treasury by public enterprises. Public enterprises are considered to be all nonfinancial enterprises partly held by the government, as defined by local legislation, government monopolies, funds, and other entities not part of the central government.

- Net international reserves are defined as gross international reserves less:

- the external liabilities of the central bank;

- base money; and

- government deposits at the central bank.

- Gross international reserves are defined as the sum of the following components: overseas demand deposits, overseas checks pending collection, pending transactions, foreign exchange held in the form of currency, public treasury demand and time deposits held abroad, Fund accounts, SDR holdings, any other Fund reserve tranche holdings, and any other external assets. These are defined for program purposes, following the definition presented in the Special Data Dissemination Standard (SDDS) as external assets of the National Bank of Djibouti that are readily available to and controlled by it. Reserve assets that are pledged or otherwise encumbered, for example, assets pledged for external liabilities of a third party must be excluded. Capital subscriptions to foreign financial institutions are not included in gross international reserves.

- $\quad$ External liabilities are represented by the sum of the external credit accounts and all foreign currency denominated external liabilities (not including the use of Fund and Arab Monetary Fund (AMF) credits). 
- Domestic liabilities of the bank of issue consist, for program purposes, of bank notes and coins representing Djibouti francs in circulation (excepting commercial banks and the treasury), cash held by commercial banks as well as by the treasury, and commercial bank and government agency deposits in the central bank;

- Nonconcessional foreign borrowings are defined as loans with a grant element of less than 35 percent. The calculation of the degree of concessionality of variable interest-rate loans is based on the average over 10 years of the Commercial Interest Reference Rate (CIRR) as published by the Organization for Economic Cooperation and Development (OECD) for loans of over 15 years maturity, based on the average over 6 months of the Market Interest Reference Rate (MIRR) for loans with maturities of less than 15 years. They include financial leasing and other instruments producing an external liability, whether conditional or not, on nonconcessional terms. For fixedinterest rate loans, concessionality depends on: (a) whether or not there is a deferred amortization period (grace period); (b) the length of the deferral period; and (c) the time period for repayment.

- $\quad$ For purposes of calculating the indicative targets, the following exchange rates will be used: $\$ 1=$ DF 177.72; EUR 1 = DF 220; SDR 1= DF 227.10.

\section{INFORMATION To BE GIVEN TO THE IMF STAFF}

The authorities will report the following basic data through the resident representative to the IMF staff as of January 2004, with a maximum lag of four weeks, unless otherwise indicated:

\section{A. Public Finances}

- $\quad$ Revenues: Breakdown of the total revenues with: (a) statement of taxes assessed; (b) statement of collections; and (c) statement of outstanding collections.

- Expenditures: Breakdown of the total expenditures by: payroll, equipment, maintenance, domestic and foreign interest, transfers and equipment expenditure, and peace consolidation expenditure.

- $\quad$ Bank financing, broken down into central bank and commercial banks. Total cumulative flows from January 1 of the current year to a specific date must equal the change in the outstanding amount between end-December 2003 and the date concerned.

\section{- Nonbank domestic financing.}

- External financing (committed and disbursed), broken down into loans and grants. Attach documentation for this breakdown: (a) progress in the projects concerned; and (b) status of external resource raising. 
- Cash-flow statement, updated for the current month and projection for the next month, based on the result of the preceding month.

\section{B. Arrears}

- $\quad$ Tables on the status of domestic arrears covering: (a) the current year (2004);

(b) the stock at the end of the previous year (2003); and (c) the consolidation of (a) and (b).

Tables on the status of external arrears covering: (a) the current year (2004);

(b) the stock at the end of the previous year (2003); and (c) the consolidation of (a) and (b).

\section{Money}

- $\quad$ Monetary survey.

- $\quad$ Central bank survey.

- $\quad$ Survey of commercial banks.

- $\quad$ Statement of net international reserves.

- Statement of outstanding central bank and commercial bank credit to the government.

\section{External Sector}

- Cumulative flow of loans and grants since January 1, 2004 until the month before the current month.

- Update of outstanding total debt stock, broken down between government debt and public enterprise debt.

- Updating of the payment schedule for all debt, broken down between government debt and enterprise debt.

- $\quad$ Foreign debt operations, other than those concerning the arrears mentioned above, in particular: (a) debt recently contracted and backed by the government and by the public enterprises; and (b) the new payment schedule, consolidating the service for this debt with prior outstanding debt.

\section{E. Real Sector}

- $\quad$ Execution of the Public Investment Program (PIP) since January 1 preceding the date the table was drawn up.

- $\quad$ Price index. 


\section{F. Structural Reforms}

Assessment of structural reforms. Indicate the progress achieved, explain slippages, if any, and indicate the planned completion date.

\section{G. Other Information (sic)}

Other information on principal economic and social measures adopted by the government which are expected to influence program implementation (changes in legislation, regulations, or in any other pertinent text), to be reported in a timely fashion to IMF staff for consultation or information purposes.

Annexes I (sic) to the MEFP (four weeks after the end of the quarter in question).

\section{Program Monitoring}

To improve the ministry of finance's program monitoring, coordination and monitoring of the reform program will be conducted at ministerial cabinet level by the advisor in charge of the program. He shall head a select technical committee consisting of the budget, revenues, economy, finance, treasury, external financing, and DISED directors, the SAL Coordinator, the representative of the central bank, and the IMF resident representative.

The committee will meet twice a month to take stock of the reconciliation of financial operations recorded in the treasury accounts and at the central bank and the score sheet for execution of structural measures; and to examine other subjects that might impact on program implementation. These working meetings will facilitate preparation of the monthly table of consolidated government operations, the domestic and foreign debt situation, the monetary survey, the updated cash-flow management plan, and the score sheet for execution of structural reforms. These tables will include a comparative analysis of actual results against projections and the implementation timetable, explaining slippages detected, and proposing corrective measures.

All these documents will subsequently be sent to the minister of finance, the governor of the central bank, and to the IMF staff through its resident mission.

Yacin Elmi Bouh

Minister of Economy, Finance, and

Planning, in charge of Privatization

Date:
Djama M. Haïd

Governor

Central Bank of Djibouti

Date: 